\title{
THE MARKET RESPONSE TO IMPLIED DEBT COVENANT VIOLATIONS
}

\author{
Derrald Earl Stice II
}

A dissertation submitted to the faculty of the University of North Carolina at Chapel Hill in partial fulfillment of the requirements for the degree of Doctor of Philosophy in the KenanFlagler School of Business.

Chapel Hill

2011

Approved by:

Jeffery Abarbanell

Robert Bushman

John Hand

Wayne Landsman

Darren Roulstone

Stephen Stubben 


\begin{abstract}
DERRALD STICE: The Market Response to Implied Debt Covenant Violations (Under the direction of Jeffery Abarbanell)

Previous research documents a negative stock price reaction to the announcement of debt covenant violations. I find evidence that investors price the likelihood of an earningsbased debt covenant violation on the date firms report earnings. Furthermore, I find no evidence of a negative stock price reaction to the announcement of an actual debt covenant violation when there was high likelihood of such a violation implied by previous reported earnings. My results suggest that the cost of debt covenant violations in the cross-section is higher than estimated in the previous literature.
\end{abstract}


To Hayley, Mom, and Dad 


\section{ACKNOWLEDGEMENTS}

I am grateful to my dissertation committee members, Jeffery Abarbanell (chair), Robert Bushman, John Hand, Wayne Landsman, Darren Roulstone, and Stephen Stubben for continuous support and advice. I thank Dan Amiram, Dane Christensen, Ted Christensen, Mike Drake, Mark Maffett, Eric Press, Kay Stice, Jake Thornock, and Chris Williams for helpful comments and discussions. I appreciate comments and suggestions from workshop participants at the 2010 Brigham Young University Accounting Symposium, 2010 University of Miami Rookie Camp, Hong Kong University of Science and Technology, McGill University, University of North Carolina at Chapel Hill, Pennsylvania State University, and the University of Southern California. 


\section{TABLE OF CONTENTS}

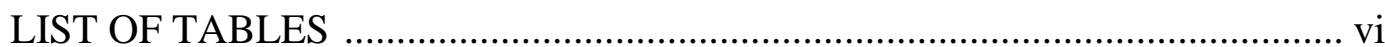

\section{THE MARKET RESPONSE TO IMPLIED DEBT \\ COVENANT VIOLATIONS ...............................................}

Introduction

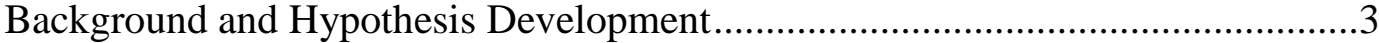

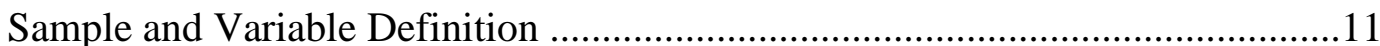

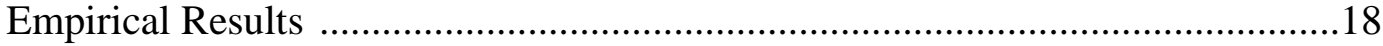

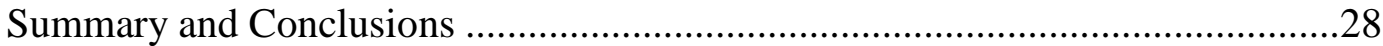

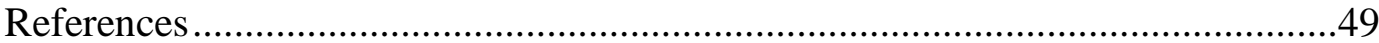




\section{LIST OF TABLES}

1. Earnings Announcement Covenant Component Disclosure............................33

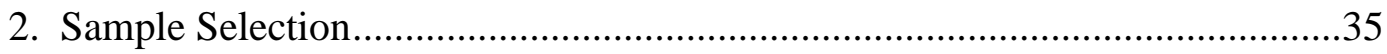

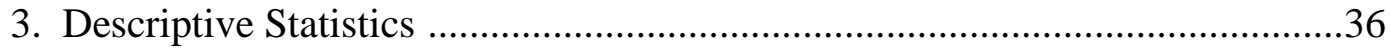

4. Debt Covenant Violation Prediction Logit Regression Results.........................38

5. Market Response to Implied Debt Covenant Violation ..................................40

6. The Market Response to Implied Debt Covenant Violation for Repeat Violators ............................................................................42

7. Market Response to Covenant Violation Reversal .......................................44

8. The Market Response to Violation Disclosure in the Financial Statements for Firms With an Earnings-Based Covenant Firms ....................................46

9. Market Response to Violation Disclosure in the Financial Statements ...........48

10. The Market Response to Implied Violation and Violation Disclosure for Accounting-based Covenant Firms 


\section{Introduction}

Prior research demonstrates there is a negative stock price reaction to the public revelation of debt covenant violations on quarterly (10-Q) and annual (10-K) filing dates (see e.g., Beneish and Press (1995)). Over half of all financial debt covenants are based on some variant of accounting earnings. Because most publicly-traded firms make a preliminary announcement of earnings weeks before the SEC filing date I investigate whether the market uses information in realized earnings to price the likelihood of a debt covenant violation (hereafter DCV) and the extent to which this reduces the stock price impact of an actual subsequent disclosure. Controlling for the information content of earnings and losses, I find evidence of a significant incremental negative price reaction on earnings announcement dates when realized earnings, ceteris paribus, imply a high likelihood of an earnings-based debt covenant violation. The result holds even when there are no explicit disclosures related to DCVs on earnings announcement dates. I also find no significant price response to the disclosure of an actual debt covenant violation on SEC filing dates for firms that previously reported earnings that implied a high likelihood of a debt covenant violation. These results complement and extend the findings of prior studies that report negative stock price reactions to the announcement of DCVs and suggest that the total costs of debt covenant violations in the cross-section are substantially higher than previously estimated.

Beneish and Press (1993) estimate the average costs of DCVs attributable to increased interest rates and renegotiation fees are between one and two percent of the market value of 
equity for their sample of firms that actually disclose a violation. In a subsequent study, Beneish and Press (1995) investigate the stock price reaction to a DCV disclosure. They find that announcements of technical default of debt covenants are associated with a significant $-3.52 \%$ return in the 3-day period surrounding announcements of debt covenant violation, $60 \%$ of which occur on the SEC filing date of the $10-\mathrm{K}$ or NT 10-K. The fact that the majority of DCV violations are disclosed on SEC filing dates suggests that firms tend to wait until the latest possible date under SEC regulations to reveal the existence of an unresolved technical default (see, Griffin, Lont, and McClune 2010). ${ }^{1}$

Because earnings are announced, on average, several weeks before financial statements are officially submitted to the SEC (see Alford, Jones and Zmijewski, 1994), it is possible that new information about possible earnings-based DCVs becomes available to investors well before the firm officially acknowledges them in an SEC filing. Consistent with this possibility Nini, Smith and Sufi (2009) report that returns are significantly negative in the months leading up to and including the SEC filing date for firms that disclose DCVs. I argue that if new information about the likelihood of DCV is revealed in announced earnings, then returns will be decreasing in a measure of that likelihood on the date of an earnings announcement. Furthermore, to the extent that this measure is positively correlated with actual DCV, I expect that the negative price response to DCV disclosures typically observed on to the SEC filing date will be attenuated.

To test these predictions I construct an earnings-announcement implied covenant violation measure using the reported earnings from the announcement, information available at

\footnotetext{
${ }^{1}$ SEC Regulation S-X states that "any breach of covenant which exists at the date of the most recent balance sheet filed and which has not been subsequently cured shall be stated in the notes to the financial statement (SEC (1988))." A more recent reiteration of this directive is reported in Sufi (2007): “... companies that are, or are reasonably likely to be, in breach of such covenants must disclose material information about that breach and analyze the impact on the company if material (SEC (2003))."
} 
the earnings announcement date, and debt covenant-specific information from Dealscan. Based on reported earnings, I calculate the debt-to-EBITDA ratio on the date of the announcement and then compare it to the stated covenant ratio at the date of the announcement. ${ }^{2}$ I validate the predictive ability of the measure on a large sample of firms, some of which report an actual DCV. The measure has predictive ability at least two quarters in advance of an actual DCV.

Next, I examine the 3-day return around earnings announcements for firms meeting data requirements for my sample. After controlling for earnings surprises and a set of control variables employed in the prior literature, I find that announcement date returns are decreasing in the measure of implied covenant violation. Furthermore, I find no evidence of a negative stock price response to a DCV on the SEC filing date among firms for which there is a disclosed debt covenant violation.

In the next section I develop my hypotheses. I describe the sample selection procedures and variables used in this study in section 3. Section 4 presents the empirical results. A summary and conclusion is provided in section 5 .

\section{Background and Hypothesis Development}

\subsection{Debt Covenants and the Costliness of Covenant Violations}

Covenants are included in debt contracts to reduce lender risk by limiting managers' ability to extract rents from debt holders and by giving lenders control of the firm during bad

\footnotetext{
${ }^{2}$ Typically this is the debt-to-EBITDA ratio from the previous quarterly earnings statement, adjusted to incorporate current period earnings, because the ratio contains several components that may not be available to the market at the earnings announcement date. I discuss the assumptions underlying the estimation of these components measures and possible biases in the next section.
} 
economic states of the firm. ${ }^{3}$ Debt holders only suffer from economic losses, and are relatively unaffected by economic gains, so they are concerned about gaining control of the firm as quickly as possible when their investment is at risk (see e.g., Aghion and Bolton, 1992). Covenant inclusion is costly to the firm, but the commitment to turning over firm control to the lender during bad states generates ex ante more favorable borrowing terms for the borrowing firm (see e.g., Bradley and Roberts, 2004).

Inclusion of debt covenants grants more favorable terms to the borrowers, however, violation is itself costly to shareholders (see Smith 1993). Gilson (1990) documents that creditors become large shareholders during bankruptcy and Baird and Rasmussen (2006) argue that even before bankruptcy, lenders exert strong influence over firms after covenant violation. Recent research also provides evidence that covenant violations are associated with a shift of firm control to lenders (see, e.g., Roberts and Sufi 2009b for a survey of his literature). For example, Nini, Smith, and Sufi (2009) find that DCV are followed by increases in CEO turnover, increases in corporate restructurings, slowdowns in mergers and acquisitions, decreases in capital expenditures, and reductions in debt use and dividend payouts. Chava and Roberts (2008) also report that capital investment decreases after financial covenant violation. Roberts and Sufi (2009a) show that covenant violations lead to restricted access to debt financing, and Sufi (2009) shows that debt covenant violations lead to decreases in the availability of lines of credit. These studies provide evidence that firms that violate debt covenants incur costs related to the transfer of control to lenders even before payment default.

\footnotetext{
${ }^{3}$ Jensen and Meckling (1976) list unwarranted distributions to shareholders, issuance of higher priority debt claims, and investments in negative net present value projects for purposes of empire building and diversification as potential actions that debt covenants attempt to prevent.
} 
Once a debt covenant is triggered, lenders can choose to accelerate the loan or renegotiate the contract. Renegotiation can be costly - Beneish and Press (1993) estimate that the average costs of DCV attributable to increased interest rates and renegotiation fees are between one and two percent of the market value of equity for their sample of firms. Roberts and Sufi (2009a) find that covenant violations are associated with increased interest rates.

DCV may also result in the costly imposition of additional covenants during the negotiation process. Core and Schrand (1999) use an option pricing framework to model firm value when firms face costs associated with DCV and test the implications of their model on a sample of thrift institutions. They find evidence that current information about a firm can affect current equity value even if that information is not correlated with future cash flows as long as that information changes the probability of violating a debt covenant in subsequent periods. That is, an increase in the number of covenants can potentially create a larger "future news" information set that negatively affects firm value, even if that news provides no information about future cash flows. ${ }^{4}$

Beneish and Press (1995) investigate the stock price reaction to a DCV disclosure. Motivated by prior studies demonstrating the costliness of violation, Beneish and Press predict that the announcement of a violation will generate a negative stock price reaction. They employ a sample of 87 firms for which accounting-based DCV was publicly disclosed in financial

\footnotetext{
${ }^{4}$ The severity of the cost of DCV has also been inferred from evidence of the exercise of managerial reporting discretion. Watts and Zimmerman (1978) posit that managers will choose accounting methods that will decrease the probability of debt covenant violation and several studies have found evidence consistent with this assertion. Sweeney (1994) finds that firms that are approaching a debt covenant violation respond with income-increasing accounting changes. DeFond and Jiambalvo (1994) examine a sample of firms that violated debt covenants and find that in the year before and in the year of the covenant violation, total accruals and working capital accruals are significantly positive. Beatty and Weber (2003) find that firms with debt covenants are more likely to adopt income increasing accounting policies than are firms without debt covenants.
} 
statements on the SEC filing date or in news media articles. Beneish and Press find that announcements of technical default of debt covenants are associated with a significant negative $3.52 \%$ return in the 3 -day period surrounding disclosure of a debt covenant violation. In documenting the association between insider trading and DCV, Griffin, Lont, and McClune (2010) provide evidence of a similar negative reaction to the announcement of DCV.

\subsection{Debt Covenant Violation Prediction}

The goal of this study is to explore the ability of the market to estimate the cost of actual DCV or, alternatively, the costs incurred to avoid a DCV that may never be directly observed by the market. This study focuses on firms with earnings-based debt covenants because the earnings announcement date provides investors the ability to immediately impound new information about the probability of a DCV without the actual disclosure of a violation. ${ }^{5}$ The use of an event study methodology increases that likelihood that earnings announcements are the source of that information. Whether the market has sufficient information to infer a change in the probability of a DCV is an empirical question.

In order to test the market reaction to an implied DCV, it is necessary to construct a measure that captures a high likelihood of covenant violation in a timely manner. A recent study by Murfin (2009) creates a measure of contract "strictness" that attempts to capture the ex ante probability of covenant violation. Murfin incorporates four measures in creating "strictness": the number of covenants, the tightness of each covenant, the scale of each covenant, and the

\footnotetext{
${ }^{5}$ Griffin, Lont, and McClune (2010) provide evidence that some informed market participants, firm insiders, begin to sell their personal holdings at least one month prior to covenant violation disclosure. However, given that they also document a negative price reaction to a DCV for their sample, it would appear that the report of changes in insider holdings is not sufficient to inform investors about the likelihood of a DCV in a timely manner.
} 
covariance of covenant ratios. An advantage of his approach is that it can be applied to a broad sample of firms. The main disadvantage of his approach for my purposes is that much of the information that goes into his measures is stale or unavailable at the earnings announcement date. ${ }^{6}$ Dyreng (2009) also develops a model of covenant violation, drawing from the bankruptcy prediction literature beginning with Beaver (1966) and Altman (1968), but his model assumes that covenant slack is a linear combination of accounting and market variables and the focus of my tests is on market reactions to new information. I include the non-market related variables used in Dyreng (2009) as controls in my tests.

Because I am interested in examining the ability of the market to infer earnings-based DCV, I require each contract in my sample to include an earnings-based covenant. After investigating the prevalence of various covenants in debt contracts and the availability of different covenant components at the earnings announcement date (see sample selection section for details) I chose to focus on debt-to-EBITDA covenant. I construct my measure by taking the contracted covenant ratio from Dealscan, information contemporaneously available, and the earnings reported at the earnings announcement date to derive an implied measure of covenant slack. I discuss the construction of the measure in more detail in the next section.

The approach I follow generates noise from at least two sources. First, the language used to specify a debt covenant varies by contract. Identically named covenants need not be identically calculated. Second, even knowing the calculation used for a specific covenant in a specific contract may not guarantee exact measurement. Variation can occur from reliance on

\footnotetext{
${ }^{6}$ Two of the components of the measure used by Murfin; the number of covenants and the covenant scale, do not change between earnings announcement dates. The remaining components; covenant slack and covenant ratio covariance, are updated quarterly using Compustat data. Thus, most of the information necessary to compute these components is not available on the earnings announcement date.
} 
non-GAAP accounting data certified by the CFO that is not publicly available (see, e.g., Leftwich 1983, Murfin 2009 and Chava and Roberts 2009). Given these concerns I define the most extreme group of negative and low slack estimates by year as the firms most likely to have violated a covenant.

\subsection{Hypothesis Development}

My first hypothesis is motivated by the logic offered in Beneish and Press (1995) for a sample of firms for which disclosure of a DCV takes place, for the most part, on the SEC filing date. Unlike Beneish and Press (1995), who use a sample of accounting-based debt covenants, it is not necessary to wait for a formal announcement from the firm or a news media article to infer DCV for my sample of earnings-based covenant firms. ${ }^{7}$ If DCV is costly and there is new information pertinent to the increased likelihood of a DCV in reported earnings, then there should be a negative price reaction to the announcement of earnings for these firms on the earnings announcement date.

Dichev and Skinner (2002) document that covenant violation occurs fairly often - 30\% of the loans in their sample - and that the most common lender response to DCV in their sample is to waive the violation. ${ }^{8}$ If implied violations, identified using my measure, are likely to be waived, then it is possible that investors will not view implied DCV as being costly. Furthermore, it is possible that an implied DCV may be associated with a positive stock price

\footnotetext{
${ }^{7}$ Beneish and Press conduct their tests using a sample of firms with accounting-based debt covenants. Over $90 \%$ of the $130 \mathrm{DCV}$ announcements examined by Beneish and Press (1995) involved violations of one or more of the following accounting-based covenants: tangible net worth, current ratio, or leverage. Only 9 of 130 violated covenants were earnings-based. Evidence presented later suggests it would not have been possible to infer violations for most other accounting-based covenants examined by Beneish and Press on earnings announcement dates.

${ }^{8}$ Dichev and Skinner (2002) also find that renegotiation is very common. Roberts and Sufi (2009c) use a large sample of private debt contracts and find that $90 \%$ of long-term debt contracts are renegotiated before maturity.
} 
reaction if minority shareholders view increased control by lenders as improving the prospect of firms with entrenched, ineffective management. For example, Nini, Smith, and Sufi (2009) document an increase in CEO turnover and corporate restructuring and a decrease in capital expenditures and debt usage after covenant violations. They find that while in the months leading up to DCV firms experience significantly negative operating cash flows and returns; these firms experience significantly positive operating cash flows and returns in the months after (see Griffin, Lont, and McClune (2010) who document a similar pattern of returns around DCV disclosure). Stocks of firms in the month of a DCV earn 5\% more than the risk-adjusted benchmark in the 12 months following violation. If actual DCVs trigger changes in firm management and strategy that investors expect will lead to subsequent improved performance, then it is possible for the market to react positively to an implied DCV.

The preceding considerations notwithstanding, I expect the market reaction observed for actual DCV in the previous literature to occur on the earnings announcement date in the case of an implied earnings-based covenant violation. Formally:

\section{H1: $\quad$ There is negative stock price reaction to the announcement of earnings that imply a violation of an earnings-based debt covenant.}

Prior studies have focused on first-time covenant violations (Beneish and Press (1995), Nini, Smith and Sufi (2009). ${ }^{9}$ First-time actual covenant violations should produce market reactions that capture the market's unbiased assessment of the full cost of a particular violation. In contrast, a sequence of implied DCVs could lead to a non-zero market reaction on each

\footnotetext{
${ }^{9}$ Beneish and Press (1995) restrict their sample to firms that disclose a violation only once during their five-year sample period.
} 
earnings announcement date. On the one hand, a string of implied DCVs may convey additional negative news or an increased likelihood of an actual DCV. Chen and Wei (1993) model the lender decision to waive a covenant violation or call the debt. They predict and find evidence consistent with lenders willingness to grant a waiver to firms with lower estimated probability of bankruptcy. Violations that occur after a waiver has been obtained in a previous period may increase the likelihood of bankruptcy and, in turn, the cost of a DCV. Thus, strings of violations may be associated with increasingly negative stock price reactions. On the other hand, if the market internalizes most of the cost of a DCV at the first implied violation then I expect that subsequent implied DCVs will produce less negative price reactions. That is, market pricing of the cost of an implied DCV that is inferred from a current earnings announcement is, in large part, pre-empted by a similar implied violation on an earlier earnings announcement date.

The argument that investors learn only marginal information about the future costs of violation after an implied DCV or, alternatively, an increased probability of an actual violation, leads to my second hypothesis:

\section{H2: The negative stock market reaction to an implied debt covenant violation will be attenuated for firms that have previously reported earnings that implied a violation.}

In the same way that equity investors' reaction to repeated violations may be tempered relative to their reaction to news of initial violations, their reaction to news that indicates a recovery in performance that may preclude the possibility of a violation may be positive. 
Violation reversals are defined as the occurrence of an implied or disclosed violation in one period followed by a lack of implied violation in the next. ${ }^{10}$ Formally, I predict:

\section{H3: $\quad$ There is a positive stock market reaction when a previous period implied debt covenant violation reverses.}

Beneish and Press (1995) find that announcements of technical default of debt covenants are associated with significant stock price declines. In their sample, the SEC filing date of the $10-\mathrm{K}$ or NT $10-\mathrm{K}$ represents the disclosure date for over $60 \%$ of observations; the remaining public disclosures of a violation are gleaned from news media reports. Griffin, Lont, and McClune (2010) also find that firms delay disclosure of covenant violations, typically reporting them in the $10-\mathrm{K}$ or $10-\mathrm{Q}$. I verify that there is a similar concentration of public disclosures in the financial statements in the sample employed in this study. Earnings-based debt covenant violations comprise less than 7\% of Beneish and Press' sample. I argue that for my sample of earnings-based covenant firms information about a possible DCV can be inferred well before financial statements are filed with the SEC. If implied violations on earnings announcement dates preempt the information in actual violations reported on an SEC filing date, then I predict the market reaction to the actual DCV announcement will be attenuated relative to firms that did not have an implied DCV before the filing date. ${ }^{11}$ This leads to my final hypothesis.

\footnotetext{
${ }^{10}$ As noted earlier, Nini, Smith, and Sufi (2009) document positive abnormal returns in the months after the announcement of an actual DCV. Lender intervention that may have lead to increases in firm efficiency, a reduction in negative NPV projects, and decreases in value-reducing manager behavior could have been the cause of improved performance associated with the reversal.

${ }^{11}$ I investigate a random sample of over 100 firm quarters for which a violation is disclosed in the financial statements. A news media article disclosing violation precedes the financial statement filing in approximately $3 \%$ of this hand-collected sample. The low incidence of filing date preemption mitigates concerns that focusing on the SEC filing date is too restrictive. Robustness tests reported later for firms with other accounting-based covenants
} 


\section{H4: The negative stock price reaction to an actual announcement of a debt covenant violation will be attenuated for firms for which it was possible to infer debt covenant violation on a previous earnings announcement date.}

\section{Sample and Variable Definition}

\subsection{Covenant Choice}

My empirical strategy is to investigate whether the market identifies and reacts to earnings announcements that imply a debt covenant violation. I focus my analysis on one particular earnings-based debt covenant, debt-to-EBITDA for two reasons. First, it is the most common debt covenant in Dealscan, a dataset of private debt agreements created by the Thomson Reuters Loan Pricing Corporation (TRLPC). A debt-to-EBITDA covenant is included in almost half of all loan agreements with financial covenants. A second reason for focusing on debt-to-EBITDA is the high frequency with which information is provided in earnings announcements that can be used to update the estimated slack in a relevant covenant benchmark.

Prior research has shown an increase in disclosures concurrent with earnings announcements (Francis, Schipper, and Vincent, 2002). To assess the availability of data to calculate debt-to-EBITDA relative to other covenants I hand-collected 50 random earnings announcements from my sample and identified the frequency with which components of widelyused debt covenants are disclosed. Panel A of table 1 indicates that $30 \%$ of the earnings announcements in the random sample provided no covenant component information other than earnings. EBITDA was explicitly disclosed in $12 \%$ of announcements. Tax expense appeared in almost two-thirds of the earnings announcements and interest expense appeared in half the

provides additional evidence that preemption of the filing date reaction by other firm disclosures related to DCV is unlikely. 
announcements. In contrast, the most commonly reported non-earnings covenant information was current assets and liabilities, which appeared in $38 \%$ of the sampled earnings announcements (always together). Updated debt and equity amounts appeared in less than a third of announcements, but not always together. Covenant components pertaining to capital expenditures, tangible assets, and cash holdings appeared in almost no earnings announcements. $^{12}$

I compared the reported covenant components to the numbers reported in the firms subsequently filed financial statements to establish the reliability of earnings announcement date disclosures. Panel B of Table 1 reports how frequently reported components were equal to the actual components that appeared in the financial statements. I observed differences for $21 \%$ of the sample. For the firms that reported the same components in the earnings announcement as in the financial statements, there was an aggregation or scale change in $53 \%$ of the observations. For example, interest income and expense was commonly netted in the earnings announcement.

Overall, the evidence in table 1 suggests that actual earnings and other disclosures on earnings announcement dates allow reliable updating of the debt-to-EBITDA ratio substantially more frequently than other covenant values.

\subsection{Implied Violation Variable Definition}

To test the hypothesis of whether the market is able to use earnings information disclosed on the earnings announcement date to predict subsequent disclosure of DCV it is necessary to construct a measure of implied DCV. I construct this measure using the reported earnings from

\footnotetext{
${ }^{12}$ Note that no firm that eventually disclosed a covenant violation in their financial statements for this random sample disclosed the violation in the preceding earnings announcement.
} 
the announcement, other information available at the earnings announcement date, and debt covenant specific information from Dealscan.

The two components needed to construct a measure of implied violation are debt-toEBITDA and the outstanding covenant ratio listed in Dealscan at the date of the announcement. The debt-to-EBITDA ratio contains several components that may not be available to the market at the earnings announcement date. As indicated above, while some firms disclose debt, interest, taxes, depreciation, amortization, or EBITDA at the earnings announcement, the majority do not. To ensure no look-ahead bias, I assume that only earnings are reported at the earnings announcement date in constructing my measure of implied DCV. I use prior period values for all components of Debt-to-EBITDA except earnings. Thus, on the earnings announcement date, reported earnings can be added to the implied violation measure to create an updated value of implied violation.

The second component needed to calculate my measure of implied violation is the contract-specific covenant value from the debt agreement. This contracted covenant value remains constant for each firm until a new debt issue is available. If a different covenant threshold is stated in the new debt agreement, the value changes to reflect the new stated contract value. Taken together, the two components create a firm-specific measure of implied violation that is updated quarterly and is calculated as follows:

$I D C V_{i, t}=$ Cov_Ratio $_{i, t}-\left(\right.$ LTD $_{\mathrm{i}, \mathrm{t}-1}+$ CurrLTD $_{\mathrm{i}, \mathrm{t}-1} / \mathrm{NI}_{t}+$ Interest $_{\mathrm{i}, \mathrm{t}-1}+\operatorname{Tax}_{\mathrm{i}, \mathrm{t}-1}+$ DepAmor $\left._{t \mathrm{i}, \mathrm{t}-1}\right)$

where, $I D C V_{i . t}$ is implied debt covenant violation for firm i in quarter $t$ constructed on the quarter t earnings announcement date; Cov_Ratio ${ }_{i, t}$ is the maximum allowable value of debt-to- 
EBITDA for firm $i$ in quarter $t$ before a technical violation occurs and, $L T D_{i, t-1}$ is long-term debt $\operatorname{CurrLTD}_{i, t-1}$ is the current portion of long-term, Interest $t_{i, t-1}$, is interest expense, $\operatorname{Tax}_{i, t-1}$ is tax expense and DepAmor ${ }_{i, t-1}$ is depreciation and amortization for firm $\mathrm{i}$ at the end of the previous quarter. $N I_{t}$ is the earnings announced that investors have the potential to use to update their expectations about a DCV. ${ }^{13}$

While the estimate of $I D C V$ is based on reported earnings, as well as earnings and balance sheet components and debt agreement covenant values available on the earnings announcement dates, there are reasons to question the precision of the measure used to predict subsequent actual DCVs. First, the use of quarter-old accounting data may limit the ability of the measure to predict subsequently disclosed DSVs. Second, the measure may be coarse because many debt contracts use transformed values of GAAP, not actual GAAP values (see, e.g., Leftwich 1983, Murfin, 2009, Chava and Roberts 2009). These concerns will bias against the ability of $I D C V$ to predict subsequent DCV disclosure because of measurement error. To mitigate the effects of the noise in $I D C V$, I rank $I D C V$ and create an indicator variable that is equal to 1 if $I D C V$ is in the most extreme quintile in a given year. ${ }^{14}$ This new variable, Implied_Violation, takes a value of 1 for the observations that most likely represent a covenant violation.

The use of Implied_Violation can lead to both Type 1 and Type 2 errors, that is, it could be incorrectly classify non-violating firms as violating and vice versa. However, I have no

\footnotetext{
${ }^{13}$ Negative values of EBITDA can produce large positive values of implied slack. Negative values of EBITDA occur in $4 \%$ of firm-quarter observations. Inferences do not change when these observations are removed.

${ }^{14}$ Inferences do not change when the most extreme quartile or decile is used.
} 
reason to believe that this potential misclassification will be systematically related to announcement date abnormal returns.

\subsection{Data and Sample Selection}

The private debt contracts represented in the Dealscan database represent a large source of corporate funds for these firms. Sufi (2007), reports that $90 \%$ of the 500 largest nonfinancial firms in COMPUSTAT obtained a loan through private channels between 1994 and 2002. The market for these loans grew to over $\$ 1$ trillion by the end of his sample period. The value of these loans grew to over $\$ 1.5$ trillion by 2005 (see Bharath, Sunder, and Sunder (2008)). I use all the debt issues of public firms in the Dealscan database that have loans with a debt-to-EBITDA covenant. Dealscan provides a unique package identification number for each debt issue as well as a company identification number and the stock ticker. I conduct my tests at the firm-deal level. ${ }^{15}$ I match these tickers with the COMPUSTAT and CRSP databases to create a dataset that includes all the loan information from Dealscan and all the financial statement information from COMPUSTAT and returns data from CRSP. I require each debt issue observation to have all the required COMPUSTAT and CRSP data. I truncate earnings at the $1^{\text {st }}$ and $99^{\text {th }}$ percentiles to remove any unwarranted impact of outliers. I include all the firm-quarters during the time period for which I have loan data that have non-missing COMPUSTAT and CRSP data for each of the firms with at least one private debt issue containing a debt-to-EBITDA covenant.

\footnotetext{
${ }^{15}$ The deal-level analysis decision is consistent with prior research and motivated in two ways. First, syndicated loan contracts are drafted at the deal level. All covenants and lenders are listed together on this contract regardless of the number of facilities (loans or lines of credit), so this is the relevant unit of observation. Second, analysis conducted at the facility level would bias standard errors downward because the same firm is associated with multiple observations (see Sufi 2007 and Murfin 2009).
} 
In preliminary tests I validate my measure of Implied Violation using a sample of known violators to provide assurance that it captures the construct of interest. The sample of known violators is the same used by Nini, Smith, and Sufi (2009). SEC filing dates are obtained from this source and verified using Perl to scan the SEC website. ${ }^{16}$ These data cover the period from 1997 to 2007, which begins when firms were required to file financial statement electronically with the SEC. Firms in the financial industry are excluded from the sample. The Nini, Smith, and Sufi sample consists of firm with DCVs that are disclosed in the financial statements.

I require sample observations to have all necessary Dealscan, COMPUSTAT, CRSP, and disclosed violation data. In addition, because my empirical design relies on the ability of the market to infer DCV from reported earnings before firm disclosure of violation in the financial statements, I require the SEC filing date to occur after the earnings announcement date for all observations. The final sample consists of 1,354 debt issues in Dealscan from 1997 to 2006. These 1,354 debt issues involve 716 unique firms. Descriptive statistics summarizing the effect of sample selection criteria on sample sizes are reported in table 2 .

\subsection{Descriptive Statistics}

Table 3 provides descriptive statistics for the sample data. Panel A reports that sample firms have an average of 2.77 financial covenants per debt issue. The minimum allowable number of financial debt covenants is one, because all debt agreements must have at least a debtto EBITDA covenant in order to be included in the sample. The maximum number of financial covenants in this sample is seven. The average loan size in the sample is $\$ 434 \mathrm{M}$, and the

\footnotetext{
${ }^{16}$ I am grateful to Greg Nini, David Smith, and Amir Sufi for making these data publicly available. The data can be found on Amir Sufi's website \{http://faculty.chicagobooth.edu/amir.sufi/\}. Please refer to the appendix in Nini et al. (2009) for more information about how the sample was collected and how it can be interpreted.
} 
average interest-spread is 211 basis points. The average contracted covenant value for debt-toEBITDA is 3.72 .

Panel B of table 3 reports descriptive statistics for the variables used in the DCV prediction model as well as the abnormal returns specifications. Covenant violations (VIOL) are reported in approximately $5 \%$ of the quarterly financial statements for the sample firms. This compares to the $7 \%$ of firm-quarter observations with a covenant violation found by Nini, Smith and Sufi, (2009). Implied violations occur in $20 \%$ of firm quarters. This rate is not surprising since the Implied_Violation variable is defined as the most extreme quintile of implied covenant slack.

The average quarterly earnings for the sample are just over $\$ 10 \mathrm{M}$, and the sample firms experience losses in $18 \%$ of firm quarters. This percentage is slightly less than the $25 \%$ documented by Hayn (1995). Average assets are $\$ 1,990 \mathrm{M}$, and the average return on assets is approximately $1 \%$. As expected, the firms contained in the sample are relatively large. The average current ratio and interest coverage ratios are 1.92 and 7.10 respectively. By comparison, the sample firms used in Dyreng (2009) have an average current ratio of 2.02 and an average interest coverage ratio of 8.45 .

I estimate abnormal returns as the 3-day average market model residuals around the event date - here the earnings announcement and financial statement filing dates - following the technique described in Collins, Li, and Xie (2009). Firms experience an average earnings announcement day abnormal return of $0.5 \%$. The average financial statement filing date abnormal return is $-0.1 \%$. On average, the financial statements are filed approximately 19 days after the earnings announcement. 
Panel C provides a correlation matrix for all of the variables. Disclosed violations are negatively associated with earnings announcement abnormal returns, interest coverage, earnings surprise, return on assets, and the natural $\log$ of assets and positively associated with losses. In general, implied earnings-based debt covenant violations are correlated in the same direction as disclosed violations. Notable exceptions are earnings surprise (SUE) and the natural log of assets. This may capture some of the fundamental differences between earnings-based debt covenant firms and "other" covenant firms. More important, disclosed violation and implied violation are positively correlated, providing a preliminary indication that the measure of implied violation is a reasonable predictor of disclosed violation.

\section{Empirical Results}

\subsection{Implied Violation Measure Validation}

Before testing my hypotheses, I validate the predictive ability of the Implied_Violation variable using the following logistic regression (firm subscripts omitted in the remainder of the paper):

$V_{I O L}+\delta=\alpha_{0}+\alpha_{1}$ Implied_Violation $_{t}+\alpha_{k}$ CONTROLS $_{t}+\gamma_{t}$

where, VIOL is an indicator variable set to 1 if a firm $i$ disclosed a debt covenant violation in its financial statements for quarter $t$ and 0 otherwise, and $\delta$ takes on the values of 0 to 4 .

If Implied_Violation correctly identifies firms that publicly disclose a debt covenant violation, then values of Implied_Violation equal to 1 should indicate a higher likelihood of future DCV disclosure in the financial statements and the coefficient, $\alpha_{l}$, will be positive. 
Focusing on the likelihood of DCV, regardless of whether the firm is in actual technical violation, is important because a violating firm may obtain a waiver or renegotiate the terms of the load without ever disclosing a violation in its financial statements. However, if waivers or renegotiations are costly, stock returns may impound this information when there is an implied DCV.

Several firm-specific characteristics are included as controls in EQ. (2) for other predictors of actual DCVs. Many of these variables have significant explanatory power. Larger firms and firms with a higher market-to-book ratio are less likely to have an actual DCV, suggesting larger and more established firms are less susceptible to violation or have a greater ability to negotiate with lenders to obtain a waiver or a renegotiated contract. The probability of and actual DCV decreases with current and last period ROA, although the coefficient on last period's ROA is not statistically significant. I also include several of the variables proposed by Dyreng (2009) that control for other common debt covenants, such as current ratio and interest coverage covenants. ${ }^{17}$ Nini, Smith and Sufi (2009) reports that the $10-\mathrm{K}$ is often a "catch-all" report in which firms report information that is not reported in the shorter quarterly reports. I include quarter fixed effects in addition to year fixed effects to control for differential quarterly reporting, and I cluster robust standard errors at the firm level.

Table 4 presents the results of estimating EQ. (2). The coefficient on Implied_Violation is positive and significant, which indicates that an implied violation at the earnings announcement date increases the probability of a firm disclosing a covenant violation in the subsequently filed financial statements. The measure of implied violation correctly identified

\footnotetext{
${ }^{17}$ Dyreng (2009) also controls for leverage. This variable has very little explanatory power for my sample of firms with a Debt-to-EBITDA covenant, so I omit it. I include leverage as a control variable for the additional sample of current ratio covenant firms. These firms have a higher incidence of leverage covenants in their debt contracts.
} 
155 of these violations. Random assignment of firms into implied violation status would have correctly identified 95 violators. This finding provides evidence that the market has the potential to use information to update their expectation of existing slack in earnings-based covenants on the earnings announcement date.

The evidence in table 4 also indicates that Implied_Violation measure has the ability to predict actual DCV at least two quarters ahead. Specifications 2 through 5 present logistic regression results for $\mathrm{VIOL}_{t+1}$ through $\mathrm{VIOL}_{t+4}$. The coefficient on Implied_Violation is positive and significant in the $t+1$ and $t+2$ specifications, and positive but insignificant in the $t+3$ and $t+4$ specifications. The magnitude of the coefficients decreases monotonically over time, consistent with a decreasing timeliness in the predictive ability of Implied_Violation.

Note that the coefficient on the indicator variable for losses, $\operatorname{Loss}_{t}$ in the quarter is significant and negative across most specifications. Jiang (2008) investigates the effect of beating earnings benchmarks on a firm's cost of debt. A main finding of that study is that the consequences of beating earnings benchmarks (zero earnings, last year's earnings, and analysts' forecasts) are different in the debt market and equity markets. Jiang finds that the loss benchmark is the most important in the debt market. This finding may partially explain the strong effect of the loss variable in this specification.

\subsection{Market Reaction to Implied Debt Covenant Violations}

The first hypothesis predicts that implied covenant violations will be associated with negative stock price reactions. To test this hypothesis I estimate the following OLS regression:

$$
E A \_C A R_{t}=\alpha_{0}+\alpha_{1} \text { Implied_Violation }_{t}+\alpha_{k} \text { CONTROLS }_{t}+\varepsilon_{t}
$$


where, $E A \_C A R_{t}$ is firm $i$ 's 3-day abnormal cumulative return centered on the earnings announcement date for quarter $t$, and Implied_Violation is as previously defined.

I include a variety of variables in the regression to control for other determinants of abnormal returns. To control for financial information arriving to the market at the earnings announcement date I include controls for losses (Hayn, 1995), earnings and lagged earnings (scaled by assets). I also control for firm characteristics, including size and market-to-book (Skinner and Sloan 2002, Fama and French 1992) and include controls for the most common non-earnings based debt covenants, current ratio and interest coverage. To control for the information content of earnings announcements I include SUE, abnormal return variance, and a measure of abnormal trading volume (Beaver 1968, Landsman and Maydew 2002, and Collins, Li, and Xie 2009). Finally, I ensure that for a random subset of my sample firms there was no explicit disclosure of a DCV on the earnings announcement date.

Table 5 presents the results for tests of H1. As predicted, the coefficient on Implied_Violation is significantly negative and it indicates that firms with an implied covenant violation experience a negative $.83 \%$ announcement abnormal return incremental to the impact of the news in earnings surprise and other variables directly associated with the information content of earnings. ${ }^{18}$ This result is consistent with a negative stock price reaction to announcement of actual DCVs on SEC filing dates and news media disclosures in the prior literature. Note that the incremental impact of losses and the market-to-book ratio on abnormal returns is also negative, while the incremental impact of ROA is positive, consistent with prior research. The addition of the control variables significantly increases the explanatory power of

\footnotetext{
${ }^{18}$ I present multiple specifications for each hypothesis to allow the reader to observe the incremental effect of adding control variables. I focus my discussion for each hypothesis test on the specification which includes all the control variables (the last column in each table).
} 
the model (in particular the addition of abnormal return variance and trading volume) without altering the inference that implied DCV are associated with negative price responses.

\subsection{Market Reaction to Repeat Violations and Violation Reversal}

$\mathrm{H} 2$ predicts that the negative stock market reaction to an implied debt covenant violation will be attenuated for firms that have previously reported earnings that implied a violation. To test this hypothesis I estimate the following OLS regression:

$$
\begin{aligned}
& \text { EA_CAR } R_{t}=\alpha_{0}+\alpha_{1} \text { Implied_Violation }_{t}+\alpha_{2} P P_{-} I D C V_{t}+\alpha 3 \text { Implied_Violation } * P P \_I D C V_{t} \\
& +\alpha_{k} \text { CONTROLS } S_{t}+\varepsilon_{t}
\end{aligned}
$$

Where, $P P \_I D C V_{t}$ is an indicator variable that is equal to 1 if firm $\mathrm{i}$ has had a prior period implied covenant violation. Specifically, $P P \_I D C V$ is equal to 1 if Implied_Violation has been equal to 1 in any of the last four quarters. The interaction Implied_Violation * PP_IDCV captures the incremental stock reaction for firms that are likely to have violated in the current period that likely violated an earnings-based covenant in a previous period. $\mathrm{H} 2$ predicts that $\alpha_{3}$ will be positive, indicating that a smaller negative reaction to an implied violation for firms that have previously had an implied violation. In this test I also control for any actual covenant violations disclosed in the financial statements within the last four quarters. I also include year fixed effects indicators and cluster robust standard errors by firm.

Table 6 presents the results for tests of $\mathrm{H} 2$. The dependent variable is again the 3-day abnormal return centered on the earnings announcement date. The coefficient on the interaction term of interest is positive and significant, consistent with the hypothesis. Note that the 
coefficient on Implied_Violation is again negative and significant, indicating that firms without prior implied debt covenant violations experience a $-1.59 \%$ abnormal return, which is almost twice as large as the estimate produced in tests of $\mathrm{H} 1$.

Hypothesis 3 predicts that firms that report earnings that imply a reversal in the likelihood of an earnings-based debt covenant violation will experience a positive stock price reaction. I create an indicator variable, $D C V \_$Reversal, that is equal to one for firms that had an implied violation or disclosed a violation in the previous quarter and do not have an implied violation in the current period. I test $\mathrm{H} 3$ by estimating the following regression:

$E A \_C A R_{t}=\alpha_{0}+\alpha_{1} D C V_{-}$Reversal $_{t}+\alpha_{k}$ CONTROLS $S_{t}+\varepsilon_{t}$

Table 7 presents results for tests of $\mathrm{H} 3$. The coefficient on DCV_Reversal is positive and significant, indicating a positive abnormal return for firms with a reversal in an implied violation between earnings announcements.

\subsection{Market Reaction to Covenant Violation Disclosed in the Financial Statements}

Hypothesis 4 predicts that the negative stock price reaction to an actual announcement of a debt covenant violation will be attenuated for firms for which it was possible to infer a debt covenant violation at the earnings announcement date. To test this hypothesis, I estimate the following OLS regression:

$S E C_{-} C A R_{t}=\alpha_{0}+\alpha_{1}$ IIOL $_{t}+\alpha_{k}$ CONTROLS $S_{t}+\varepsilon_{t}$ 
Where, $S E C \_C A R_{t}$ is firm $i$ 's 3-day abnormal cumulative return centered on the financial statement filing date for quarter $t$, and $V I O L$ is an indicator variable that is equal to 1 if a covenant violation was disclosed in the financial statements for the quarter. Recall that VIOL is the dependent variable in the logit models used to validate the implied violation measure.

Table 8 presents the results of tests of H4. Models 1 and 2 are used to estimate the market reaction to the disclosure of a DCV for firms with an actual earnings-based covenant and an implied covenant violation, respectively. I predict that the coefficient on disclosed violations will be smaller for these firms than for firms without an earnings-based covenant or implied covenant violation. The coefficient on VIOL is indistinguishable from zero in both specifications. This table provides strong evidence of the absence of a negative reaction to DCV disclosure in the financial statements for firms with an earnings-based debt covenant, suggesting earnings information preempts the impact of an actual DCV disclosure, consistent with H4.

\subsection{Alternative Explanations and Additional Tests}

The motivation for this study is to assess whether the market has the ability to infer changes in the probability of DCV at the announcement of earnings for firms that have earningsbased debt covenants. Hypothesis 4 predicts and finds that there is no negative reaction to disclosed DCVs for these firms. One potential explanation for the absence of a negative reaction is a change in the information environment of borrowing firms since Beneish and Press (1995) conducted their investigation. The time period examined in their study, 1983 to 1987 , does not overlap with the period I study. Thus, it is possible that a general improvement in firm information environment subsequent to the period studied by Beneish and Press may account for the result. It may also be the case that managers are more likely in the later time period to 
release DCV information. Skinner (1994) finds that managers have incentives to preempt large negative earnings surprises by disclosing this information early. He finds that litigation and reputational costs increase when investors are surprised by bad news. These litigation and reputational costs may have increased compared to the period in the sample of Beneish and Press. Managers facing these costs may choose to disclose information about DCV before the filing of the financial statements. ${ }^{19}$

I estimate EQ. (6) using the full sample of disclosed violations provided by Nini, Smith and Sufi (2009) that have the required Compustat and CRSP data to verify that the market reacts, on average negatively to an actual DCV in the manner reported in Beneish and Press (1995) and report the results in Table 9. The first specification uses every available observation, and the second specification removes all observations that were used in my sample, i.e., all the firms that had a debt-to-EBITDA covenant. The disclosure of a violation is associated with a significant negative abnormal return on the financial statement filing date. Both specifications yield an abnormal return of approximately negative $.45 \%$ after controlling for financial, risk, and market factors. This table provides results consistent with the market reacting to the disclosure of covenant violations in the financial statements and mitigates concerns that the market reaction to DCV disclosure has changed over time.

A second alternative explanation for my findings is that in constructing a sample of firms that have an earnings-based debt covenant in Dealscan, I may have captured artifacts peculiar to "Dealscan" firms that account for the fact that I observe no market reaction to DCV on SEC filing dates. For example, firms in the Dealscan database may be fundamentally different than

\footnotetext{
${ }^{19}$ Recall, however, that the hand-collection sample of firm disclosures around earnings announcements and financial statement filing dates provided little evidence of firm disclosure about covenant violation before the financial statement filing date.
} 
those used in the Beneish and Press sample because the Dealscan database is composed of private debt contracts and some prior studies conclude that private debt has advantages over public debt with respect to monitoring efficiency, access to private information, and the ease of liquidation and renegotiation in periods of financial distress (see, e.g., Denis and Mihov, 2003). In contrast, the sample employed in Beneish and Press (1995) contained both public and private debt agreements. However, the preponderance of firms in their sample had private lending, making it less likely that the absence of public debt in my sample accounts for differences. ${ }^{20}$ While it is unlikely that sample composition and period differences account for the absence of a market reaction to debt covenant violations on SEC filing dates, I address these concerns by constructing a sample of 277 firms with debt contracts covered in Dealscan for which there are only non-earnings-based debt covenants. In particular, all of the firms in this subsample have a current ratio debt covenant. Additional accounting-based debt covenants also included in the debt agreements (of the current ratio firms) are maximum allowable capital expenditure, maximum debt-to-equity, and maximum debt-to-net worth. This sample covers the same time period as my main sample. I predict that the market's ability to infer the likelihood of DCV on the earnings announcement date will be weaker than for the earnings-based covenant sample. In addition, the disclosure of DCV on the SEC filing date should be more informative to the market. If there is a negative stock price reaction to the disclosure of DCV for this sample of firms, it will mitigate some of the concerns discussed above and strengthen the argument that the lack of market response on the SEC filing date for the main sample is attributable the market inferring information about a potential earnings-based violation on the earnings announcement date.

\footnotetext{
${ }^{20}$ Beneish and Press (1993) state that 87of the 91 firms in their sample had private debt agreements (pg. 235).
} 
The results reported in table 10 for Model 1 for which announcement abnormal returns on the SEC filing date serve as the depend variable are consistent this argument. For the sample of firms with an accounting-based debt covenant, there is a significant (at the $7 \%$ level), negative stock price reaction to the disclosure of DCV in the financial statements. A negative reaction is observed after controlling for other common accounting-based covenants such as leverage and capital expenditure.

Table 10 reports results for Model (2), which estimates the market response to earnings announced prior to an SEC filing date. The model intentionally exploits look-ahead bias by including an indicator for firms that eventually violate the current ratio covenant. The evidence from this model indicates there is no market reaction on the preceding earnings announcement date.

Overall, table 10 provides evidence that for firms with a non-earnings-based debt covenant violation, there is a negative stock price reaction on the filing date but no reaction of the earnings announcement date. These results reinforce the conclusion drawn from the evidence in table 8, that the lack of a significant price reaction to the disclosure of DCV on the SEC filing date for firms with an earnings-based debt covenant is attributed to preemptive information provided in earnings announcements.

\section{Summary and Conclusions}

In this paper I construct a measure with information in firms' earnings announcements that successfully predicts the incidence of subsequent earnings-based debt covenant violations. I predict and find that the market is able to infer likely earnings-based debt covenant violations on the earnings announcement date using publicly available information. These implied debt 
covenant violations are associated with significant negative stock price reactions on the earnings announcement date. I also find that the stock price reaction to implied violation is smaller when an implied violation has occurred in the previous four quarters. These results complement the findings of prior studies that report negative stock price reactions to the announcement of DCVs. In contrast to evidence in prior studies I find no evidence of a negative market reaction to the disclosure of a DCV on the SEC filing date in the case of firms with and implied earnings-based DCV.

Analysis of the implicit and explicit costs of DCV in prior studies typically begins with samples of firms that disclose an actual debt covenant violation. The market reaction to the disclosure is commonly used as a proxy for the cost of a violation. However, my results suggest that to the extent that the market can exploit publically available accounting information to infer a DCV that is subsequently disclosed (or occurred but was settled by waiver, renegotiation, or shifting of control rights), market reactions on the date of disclosure will understate the total costs of DCV in the cross-section.

I also find evidence that the market reacts less negatively to information about a possible covenant violation when an implied DCV has been observed in the previous period. This evidence suggests additional complications in using market returns over given event windows to gauge the costs of debt covenant violations, because it is not clear when information becomes "public." Further complication in assessing the cost of DCVs is suggested by evidence that investors react positively to accounting information that implies a reversal in the probability of an earnings-based debt covenant.

This study extends the literature that documents a negative stock price reaction to the announcement of debt covenant violation. I show that negative price reactions to information 
that implies debt covenant violations occur in advance of actual disclosures. Robustness tests confirm that my results are not likely to be an artifact of changes in the information environment of firms with private debt over time or differences in characteristics of sample firms or loan types covered by Dealscan and those of firms on which conclusions from the prior literature have been drawn. 


\section{Table 1: Earnings Announcement Covenant Component Disclosure*}

Panel A: This panel presents descriptive statistics for debt covenant data reported in the earnings announcement.

\begin{tabular}{lc}
\multicolumn{1}{c}{ Disclosure Item } & $\begin{array}{c}\text { \% of firms } \\
\text { disclosing }\end{array}$ \\
\hline Earnings & $100 \%$ \\
Only Earnings (No other covenant components)** & $30 \%$ \\
DCV Disclosure*** & $0 \%$ \\
Only IS Info & $31 \%$ \\
& \\
EBITDA & $12 \%$ \\
Interest & $50 \%$ \\
Tax Expense & $62 \%$ \\
Depreciation \& Amortization & $30 \%$ \\
Equity & $34 \%$ \\
LTD & $30 \%$ \\
Current Portion of LTD & $2 \%$ \\
Current Liabilities & $38 \%$ \\
Current Assets & $38 \%$ \\
Intangible Assets & $0 \%$ \\
Capital Expenditure & $2 \%$ \\
Cash \& Equivalents & $6 \%$ \\
& \\
\hline
\end{tabular}


Panel B: This panel provides statistics comparing covenant data from the financial statements to data reported in the earnings announcement.

\section{Comparison Metric}

Firms reporting the same

information in the financial

statements that was reported in

the earnings announcement

Firms reporting different

information in the financial

statements that was reported in

the earnings announcement

Firms reporting the same

information in the financial

statements that aggragated

covenant component information

or significantly altered the

reporting units of measurement
$21 \%$

$\%$ of firms

$79 \%$

$53 \%$

*I search for components of the following covenants: capital expenditure, debt-to-EBITDA, leverage, cash interest coverage, current ratio, interest coverage.

**The percent of firms that disclose no covenant component information other than earnings. These firms may disclose other financial information.

***The percent of firms that disclose a debt covenant violation at the earnings announcement that will eventually disclose violation in the financial statements. 


\section{Table 2: Sample selection}

Panel A: This panel presents the effect of sample selection criteria on the loan sample size.

Filters

Number of Loans

All loans with a borrowing firm

ticker

42,315

Loans with Debt-to EBITDA

covenant

Match with Compustat identifier,

eliminate firms without loan

identifier, eliminate loans issued

outside of sample period 1997 to

2006

1,978

Eliminate Loans with missing data

1,354

Panel B:This panel presents the effect of sample selection criteria on firm-quarter sample size.

Filters

Number of Firm-Quarters

All firm-quarter observations from

Panel A

Eliminate firms that report earnings

on the same day they file their

financial statements

Eliminate firms with missing data and

truncate variables

11,440 


\section{Table 3: Descriptive Statistics}

\section{Panel A: Loan Characteristics}

\begin{tabular}{lcccccc} 
Loan Characteristics: & $\begin{array}{c}\text { Number of } \\
\text { Observations }\end{array}$ & Mean & Std Dev & 25th Pctl & Median & 75th Pctl \\
\hline Number of Financial Covenants & 1,354 & 2.77 & 1.01 & 2.00 & 3.00 & 3.00 \\
Loan Size (in millions) & 1,354 & 434.14 & $1,069.23$ & 75.00 & 190.00 & 400.00 \\
Interest Spread (in bps) & 1,290 & 211.53 & 55.58 & 200.00 & 200.00 & 200.00 \\
Number of Lenders & 1,220 & 55.01 & 7.34 & 51.00 & 51.00 & 51.00
\end{tabular}

Panel B: Sample Characteristics

\begin{tabular}{|c|c|c|c|c|c|}
\hline & & & & & \\
\hline VIOL (Disclosed Violation) & 0.047 & 0.21 & 0.00 & 0.00 & 0.00 \\
\hline Implied_Violation & 0.22 & 0.41 & 0.00 & 0.00 & 0.00 \\
\hline$N I_{t}($ in millions $)$ & 10.04 & 359.76 & 0.87 & 6.30 & 19.33 \\
\hline$N I_{t-1 \text { (in millions) }}$ & 11.28 & 263.05 & 0.80 & 5.95 & 18.43 \\
\hline $\operatorname{Loss}_{t-1}$ & 0.18 & 0.39 & 0.00 & 0.00 & 0.00 \\
\hline Int_Coverage $_{t-1}$ & 7.10 & 1.62 & 0.19 & 2.04 & 5.95 \\
\hline$S U E_{t}$ & 0.002 & 0.049 & -0.005 & 0.000 & 0.006 \\
\hline$R O A_{t}$ & 0.01 & 0.04 & 0.00 & 0.01 & 0.02 \\
\hline Assets $_{t-1}$ (in millions) & $1,990.92$ & 25.20 & 0.41 & 681.76 & $1,646.40$ \\
\hline Ln_Assets ${ }_{t-1}$ & 6.54 & 1.36 & 5.67 & 6.50 & 7.38 \\
\hline Curr_Ratio $_{t-1}$ & 1.92 & 1.10 & 1.19 & 1.70 & 2.40 \\
\hline Cov_Ratio & 3.72 & 1.45 & 3.00 & 3.50 & 4.50 \\
\hline$L n_{-} M V E_{t}$ & 6.30 & 1.52 & 5.35 & 6.35 & 7.27 \\
\hline$L n \_M T B_{\mathrm{t}-1}$ & 0.70 & 0.81 & 0.21 & 0.67 & 1.14 \\
\hline$E A_{-} C A R_{t}$ & 0.01 & 0.09 & -0.04 & 0.00 & 0.05 \\
\hline$S E C_{-} C A R_{t}$ & 0.00 & 0.06 & -0.02 & 0.00 & 0.02 \\
\hline$E A \_A V A R$ & 14.28 & 29.45 & 1.85 & 5.04 & 13.59 \\
\hline$E A \_A V O L$ & 3.45 & 6.28 & -0.24 & 1.57 & 4.89 \\
\hline File_Announce_Difference & 18.94 & 13.95 & 9.00 & 16.00 & 25.00 \\
\hline
\end{tabular}


Panel D: Correlation Matrix

\begin{tabular}{|c|c|c|c|c|c|c|c|c|c|}
\hline & $\begin{array}{c}\text { VIOL } \\
\text { (Disclosed } \\
\text { Violation) }\end{array}$ & Implied_Violation & $E A \_C A R$ & $R O A_{t}$ & $R O A_{t-1}$ & $\operatorname{Loss}_{t}$ & SUE & $M T B$ & ${ }_{\text {Ln_Assets }}{ }_{t-1}$ \\
\hline \multirow[t]{2}{*}{ VIOL (Disclosed Violation) } & & 0.058 & -0.040 & -0.151 & -0.095 & 0.217 & -0.029 & -0.121 & -0.099 \\
\hline & & $<.0001$ & $<.0001$ & $<.0001$ & $<.0001$ & $<.0001$ & 0.002 & $<.0001$ & $<.0001$ \\
\hline \multirow[t]{2}{*}{ Implied_Violation } & 0.058 & & -0.030 & -0.101 & -0.102 & 0.149 & 0.027 & -0.109 & 0.138 \\
\hline & $<.0001$ & & 0.002 & $<.0001$ & $<.0001$ & $<.0001$ & 0.004 & $<.0001$ & $<.0001$ \\
\hline \multirow[t]{2}{*}{$E A \_C A R$} & -0.040 & -0.030 & & 0.063 & 0.003 & -0.075 & 0.020 & -0.023 & -0.008 \\
\hline & $<.0001$ & 0.002 & & $<.0001$ & 0.720 & $<.0001$ & 0.035 & 0.014 & 0.382 \\
\hline \multirow[t]{2}{*}{$R O A_{t}$} & -0.151 & -0.101 & 0.063 & & 0.261 & -0.499 & 0.334 & 0.302 & -0.011 \\
\hline & $<.0001$ & $<.0001$ & $<.0001$ & & $<.0001$ & $<.0001$ & $<.0001$ & $<.0001$ & 0.236 \\
\hline \multirow[t]{2}{*}{$R O A_{t-1}$} & -0.095 & -0.102 & 0.003 & 0.261 & & -0.241 & -0.371 & 0.245 & 0.008 \\
\hline & $<.0001$ & $<.0001$ & 0.720 & $<.0001$ & & $<.0001$ & $<.0001$ & $<.0001$ & 0.403 \\
\hline \multirow[t]{2}{*}{$\operatorname{Loss}_{t}$} & 0.217 & 0.149 & -0.075 & -0.499 & -0.241 & & -0.101 & -0.228 & -0.027 \\
\hline & $<.0001$ & $<.0001$ & $<.0001$ & $<.0001$ & $<.0001$ & & $<.0001$ & $<.0001$ & 0.004 \\
\hline \multirow[t]{2}{*}{$S U E$} & -0.029 & 0.027 & 0.020 & 0.334 & -0.371 & -0.101 & & 0.042 & -0.007 \\
\hline & 0.002 & 0.004 & 0.035 & $<.0001$ & $<.0001$ & $<.0001$ & & $<.0001$ & 0.448 \\
\hline \multirow[t]{2}{*}{$M T B$} & -0.121 & -0.109 & -0.023 & 0.302 & 0.245 & -0.228 & 0.042 & & 0.098 \\
\hline & $<.0001$ & $<.0001$ & 0.014 & $<.0001$ & $<.0001$ & $<.0001$ & $<.0001$ & & $<.0001$ \\
\hline \multirow[t]{2}{*}{${ }_{L n \_A s s e t s} t-1$} & -0.099 & 0.138 & -0.008 & -0.011 & 0.008 & -0.027 & -0.007 & 0.098 & \\
\hline & $<.0001$ & $<.0001$ & 0.382 & 0.236 & 0.403 & 0.004 & 0.448 & $<.0001$ & \\
\hline
\end{tabular}


Table 4: Debt Covenant Violation Prediction Logit Regression Results

Probability Modeled: VIOL $=1$

\begin{tabular}{|c|c|c|c|c|c|c|c|c|c|c|}
\hline & \multicolumn{2}{|c|}{ VIOL $_{t}=1$} & \multicolumn{2}{|c|}{ VIOL $_{t+1}=1$} & \multicolumn{2}{|c|}{$\mathrm{VIOL}_{t+2}=1$} & \multicolumn{2}{|c|}{ VIOL $_{t+3}=1$} & \multicolumn{2}{|c|}{ VIOL $_{t+4}=1$} \\
\hline & \multicolumn{2}{|c|}{ (1) } & \multicolumn{2}{|c|}{$(2)$} & \multicolumn{2}{|c|}{$(3)$} & \multicolumn{2}{|c|}{$(4)$} & \multicolumn{2}{|c|}{$(5)$} \\
\hline VARIABLES & $\begin{array}{c}\text { Coefficient } \\
\text { Estimate }\end{array}$ & Pr $>$ ChiSqr & $\begin{array}{c}\text { Coefficient } \\
\text { Estimate }\end{array}$ & $\operatorname{Pr}>C h i S q r$ & $\begin{array}{c}\text { Coefficient } \\
\text { Estimate } \\
\end{array}$ & Pr $>$ ChiSqr & $\begin{array}{c}\text { Coefficient } \\
\text { Estimate }\end{array}$ & $\operatorname{Pr}>C h i S q$ & $\begin{array}{c}\text { Coefficient } \\
\text { Estimate }\end{array}$ & Pr>ChiSqr \\
\hline Intercept & -0.6559 & 0.0889 & -0.8754 & 0.0322 & -0.8150 & 0.0548 & -1.0812 & 0.0137 & -1.2564 & 0.0074 \\
\hline Implied_Violation & 0.6473 & $<.0001$ & 0.5749 & 0.0003 & 0.5270 & 0.0019 & 0.2395 & 0.1897 & 0.0595 & 0.7674 \\
\hline$R O A_{t}$ & -8.1109 & $<.0001$ & -5.5113 & 0.0002 & -8.0764 & $<.0001$ & -8.1518 & $<.0001$ & -2.9573 & 0.0767 \\
\hline$R O A_{t-1}$ & -1.4559 & 0.1408 & -0.7396 & 0.5132 & 1.1319 & 0.3912 & 1.4751 & 0.2983 & -2.2539 & 0.0783 \\
\hline $\operatorname{Loss}_{t-1}$ & 0.7962 & $<.0001$ & 0.9752 & $<.0001$ & 0.5266 & 0.0023 & 0.3242 & 0.0629 & 0.4878 & 0.0176 \\
\hline Int_Coverage $_{t-1}$ & 0.0002 & 0.0884 & 0.0001 & 0.3432 & 0.0000 & 0.7830 & 0.0000 & 0.6701 & 0.0002 & 0.0665 \\
\hline$S U E$ & 0.2490 & 0.2822 & -0.2490 & 0.2556 & 1.1480 & 0.0235 & 1.1565 & 0.0144 & -0.3913 & 0.0630 \\
\hline$M T B_{\mathrm{t}}$ & -0.3948 & 0.0004 & -0.3222 & 0.0024 & -0.3435 & 0.0009 & -0.3097 & 0.0049 & -0.2569 & 0.0192 \\
\hline Ln_Assets $_{t-1}$ & -0.3609 & $<.0001$ & -0.3237 & $<.0001$ & -0.3134 & $<.0001$ & -0.3020 & $<.0001$ & -0.2901 & $<.0001$ \\
\hline Curr_Ratio ${ }_{t-1}$ & -0.0960 & 0.1124 & -0.0298 & 0.6195 & -0.0398 & 0.5292 & 0.0009 & 0.9885 & -0.0198 & 0.7782 \\
\hline Cov_Ratio & -0.0401 & 0.4410 & -0.0744 & 0.1893 & -0.0509 & 0.4292 & -0.0506 & 0.4275 & -0.0432 & 0.5425 \\
\hline Fixed Effects & $\mathrm{Yr}$, & Qtr & $\mathrm{Yr}$, & Qtr & $\mathrm{Yr}$, & Qtr & $\mathrm{Yr}$ & Qtr & & Qtr \\
\hline Clustered SE & & $\mathrm{rm}$ & & irm & & irm & & irm & & irm \\
\hline $\mathrm{N}_{\mathrm{VIOL}=0}$ & & 46 & & 731 & & 24 & & 257 & & 644 \\
\hline $\mathrm{N}_{\mathrm{VIOL}=1}$ & & 73 & & 72 & & 06 & & 58 & & 16 \\
\hline R-squared & 0.0 & 505 & 0.0 & 435 & 0.0 & 331 & 0.0 & 254 & 0.0 & 222 \\
\hline Max-rescaled R-Squared & & 16 & 0.1 & 398 & 0.1 & 118 & 0.0 & 894 & & 082 \\
\hline
\end{tabular}


Table 4 presents results from a logistic regression of the following model using firm-quarters over the period 1997 to 2006:

$$
\begin{aligned}
& \text { VIOL }_{t+\delta}=\alpha_{0}+\alpha_{1} \text { Implied_Violation }_{t}+\alpha_{3} \text { ROA }_{t}+\alpha_{4} \text { ROA }_{t-1}+\alpha_{4} \text { Loss }_{t}+\alpha_{5} \text { Int_Coverage }_{t-1}+\alpha_{6} \text { SUE }_{t-1}+ \\
& \alpha_{7} \text { MTB }_{t-1}+\alpha_{8} \text { Ln_Assets }_{t-1}+\alpha_{9} \text { Curr_Ratio }_{t-1}+\alpha_{10} \text { Cov_Ratio } \\
& t
\end{aligned}
$$

$V I O L$ is an indicator variable that $=1$ if a firm $i$ disclosed a debt covenant violation in its financial statements for quarter $t$ and $=0$ otherwise and $\delta$ takes the values of 0 to 4 . Implied_Violation is an indicator variable that $=1$ for the most extreme quintile by year of implied covenant slack, constructed on the earnings announcement date for quarter $t$ and $=0$ otherwise. $R O A_{t}$ is net income for firm $i$ in quarter $t$ divided by assets in quarter $t-1 . R O A_{t-1}$ is the return on assets for quarter $t-1$. Loss $t_{t}$ is in indicator variable $=1$ if the firm experienced a loss in quarter $t$.

Int_Coveraget $_{-1}$ is the interest coverage ratio for firm $i$ in quarter $t-1$. SUE is earnings for quarter $t$ less earnings for quarter $t-1$ scaled by the market value of equity in quarter $t-1$ for firm $i$. Ln_Assets $s_{t-1}$ is the natural log of assets for quarter $t-i$. Curr_Ratio $t_{\mathrm{t}-1}$ is current assets divided by current liabilities for quarter $t-1$. Cov_Ratio is the maximum allowable value of debt-to EBITDA for firm $i$ in quarter $t$ before a technical violation occurs. The standard errors are clustered by firm. Year and quarter fixed effects are included. 
Table 5: Market Response to Implied Debt Covenant Violation

Dependent Variable: EA_CAR

\begin{tabular}{|c|c|c|c|c|c|c|c|c|}
\hline VARIABLES & $\begin{array}{c}\text { Coefficient } \\
\text { Estimate }\end{array}$ & $\operatorname{Pr}>|t|$ & $\begin{array}{c}\text { Coefficient } \\
\text { Estimate }\end{array}$ & $\operatorname{Pr}>|t|$ & $\begin{array}{c}\text { Coefficient } \\
\text { Estimate }\end{array}$ & $\operatorname{Pr}>|t|$ & $\begin{array}{c}\text { Coefficient } \\
\text { Estimate }\end{array}$ & $\operatorname{Pr}>|t|$ \\
\hline Intercept & 0.0066 & 0.0024 & 0.0082 & 0.1438 & 0.0086 & 0.2339 & 0.0077 & 0.2652 \\
\hline Implied_Violation & -0.0066 & 0.0013 & -0.0062 & 0.0026 & -0.0077 & 0.0009 & -0.0083 & 0.0003 \\
\hline $\operatorname{Loss}_{t-1}$ & & & -0.0092 & 0.0037 & -0.0091 & 0.0075 & -0.0089 & 0.0103 \\
\hline $\mathrm{ROA}_{t}$ & & & 0.1395 & 0.0231 & 0.1545 & 0.0179 & 0.1641 & 0.0139 \\
\hline$S U E$ & & & 0.1155 & $<.0001$ & 0.1149 & $<.0001$ & 0.1144 & $<.0001$ \\
\hline$M T B$ & & & -0.0060 & 0.0002 & -0.0062 & $<.0001$ & -0.0060 & $<.0001$ \\
\hline Ln_Assets ${ }_{t-1}$ & & & 0.0003 & 0.6959 & -0.0003 & 0.6755 & -0.0001 & 0.9400 \\
\hline Int_Coverage $_{t-1}$ & & & & & 0.0000 & 0.3241 & 0.0000 & 0.1447 \\
\hline Curr_Ratio $_{t-l}$ & & & & & -0.0006 & 0.5570 & -0.0003 & 0.7577 \\
\hline Cov_Ratio & & & & & 0.0016 & 0.0799 & 0.0017 & 0.0716 \\
\hline$E A \_A V A R$ & & & & & & & -0.0019 & $<.0001$ \\
\hline$E A \_A V O L$ & & & & & & & 0.0003 & $<.0001$ \\
\hline Fixed Effects & \multicolumn{2}{|c|}{ Year } & \multicolumn{2}{|c|}{ Year } & \multicolumn{2}{|c|}{ Year } & \multicolumn{2}{|c|}{ Year } \\
\hline Clustered SE & \multicolumn{2}{|c|}{ Firm } & \multicolumn{2}{|c|}{ Firm } & \multicolumn{2}{|c|}{ Firm } & \multicolumn{2}{|c|}{ Firm } \\
\hline Number of Observations & \multicolumn{2}{|c|}{11,440} & \multicolumn{2}{|c|}{10,912} & \multicolumn{2}{|c|}{9,528} & \multicolumn{2}{|c|}{9,528} \\
\hline R-squared & \multicolumn{2}{|c|}{0.0020} & \multicolumn{2}{|c|}{0.0144} & \multicolumn{2}{|c|}{0.0155} & \multicolumn{2}{|c|}{0.0294} \\
\hline
\end{tabular}


Table 5 presents results from the OLS estimation of the following model using firm-quarter earnings announcements over the period 1997 to 2006 :

$$
\begin{aligned}
& \text { EA_CAR } R_{t}=\alpha_{0}+\alpha_{1} \text { Implied_Violation }_{t}+\alpha_{2} \text { Loss }_{t}+\alpha_{3} \text { ROA }_{t}+\alpha_{4} S U E_{t-1} \\
& +\alpha_{5} M T B+\alpha_{6} \text { Ln_Assets }_{t-1}+\alpha_{7} \text { Int_Coverage } e_{t-1}+\alpha_{8} \text { Curr_Ratio }_{t-1}+\alpha_{9} \text { Cov }_{-} \text {Ratio }_{t} \\
& \alpha_{10} E A \_A V A R s_{t-1}+\alpha_{11} \text { EA_AVOLs }_{t-1}+\gamma_{t}
\end{aligned}
$$

$E A_{-} C A R_{t}$ is firm $i$ 's 3-day abnormal cumulative return centered on the earnings announcement date for quarter $t$. Implied_Violation is an indicator variable that $=1$ for the most extreme quintile by year of implied covenant slack, constructed on the earnings announcement date for quarter $t$ and $=0$ otherwise. $R O A_{t}$ is net income for firm $i$ in

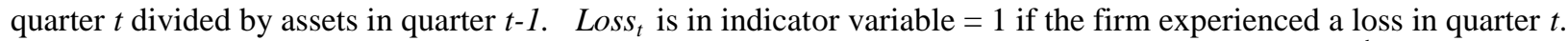
Int_Coveraget $_{-1}$ is the interest coverage ratio for firm $i$ in quarter $t-l$ and is truncated at the $1^{\text {st }}$ and $99^{\text {th }}$ percentiles. $S U E$ is earnings for quarter $t$ less earnings for quarter $t-1$ scaled by the market value of equity in quarter $t-1$ for firm $i$ and is truncated at the $1^{\text {st }}$ and $99^{\text {th }}$ percentiles. $L n_{-} M V E_{t-1}$ is the natural $\log$ of the market value of equity for quarter $\mathrm{t}-1$. MTB is the natural $\log$ of the market value of equity divided by the book value of equity in quarter $t-1$.

Curr_Ratio $o_{\mathrm{t}-1}$ is current assets divided by current liabilities for quarter $t-1$. Cov_Ratio is the maximum allowable value of debt-to-EBITDA for firm $i$ in quarter $t$ before a technical violation occurs. EA_AVAR is the 3-day abnormal variance centered around the earnings announcement date for firm $i$ in quarter $t$. EA_AVOL is the 3-day abnormal trading volume centered around the earnings announcement date for firm i in quarter $t$. The standard errors are robust to heteroskedasticity and clustered by firm. Year fixed effects are included. 
Table 6: Market Response to Implied Debt Covenant Violation

for Repeat Violators

Dependent Variable: EA_CAR $_{t}$

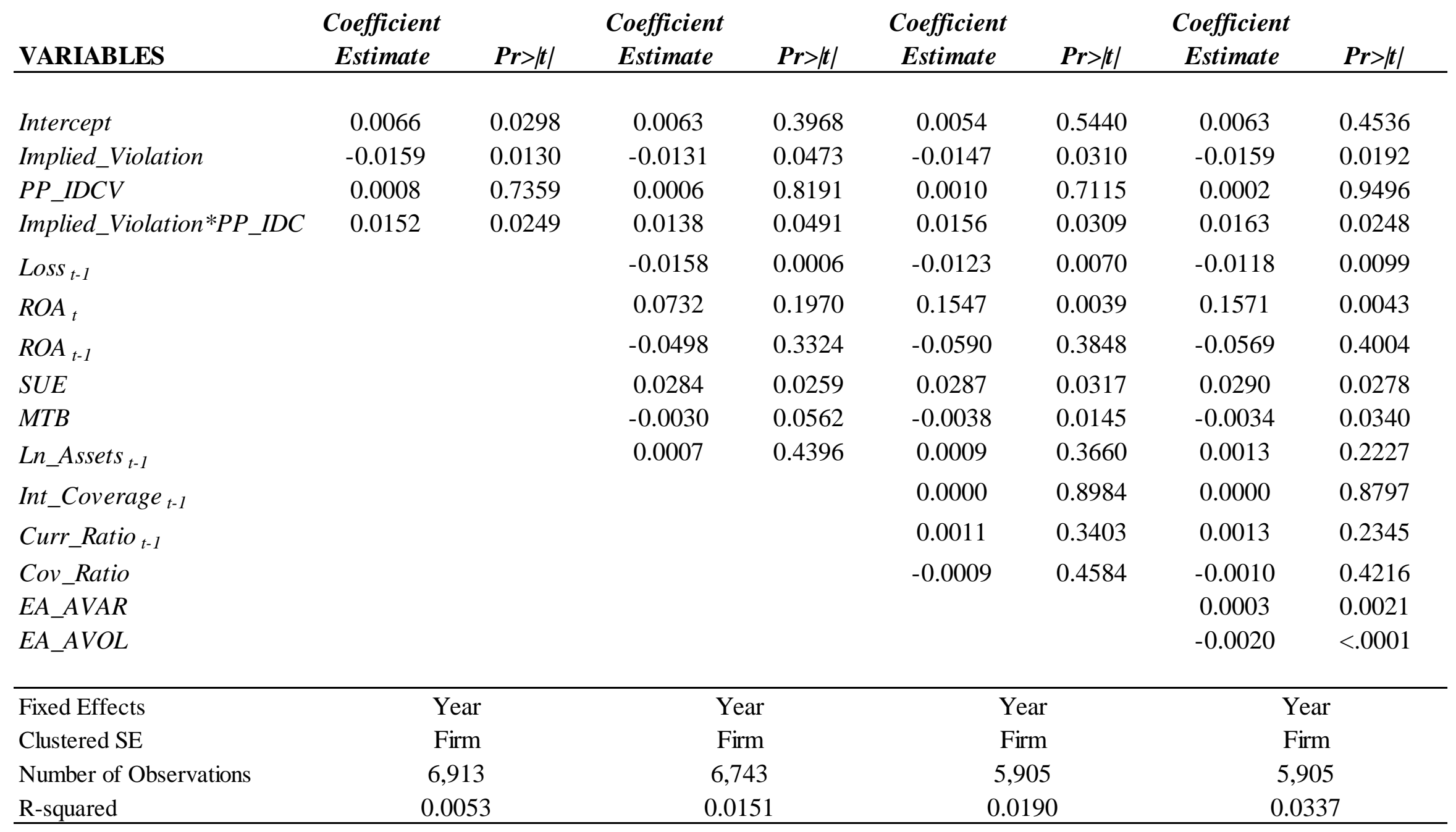


Table 6 presents results from the OLS estimation of the following model using firm-quarter earnings announcements over the period 1997 to 2006 :

$$
\begin{aligned}
& E A \_C A R_{t}=\alpha_{0}+\alpha_{1} I m p l i e d \_ \text {Violation }_{t}+\alpha_{2} P P \_I D C V_{t}+\alpha_{3} \text { Implied_Violation }^{*} P P \_I D C V_{t}+\alpha_{4} \text { Loss }_{t} \\
& +\alpha_{5} R O A_{t}+\alpha_{6} R O A_{t-1}+\alpha_{7} S U E_{t-1}+\alpha_{8} M T B+\alpha_{9} L_{-} \text {Assets }_{t-1}+\alpha_{10} \text { Int_Coverage }_{t-1}+\alpha_{11} \text { Curr_Ratio }_{t-1} \\
& +\alpha_{12} \text { Cov_Ratio }{ }_{t}+\alpha_{13} E A \_A V A R s_{t-1}+\alpha_{14} E A \_A V O L s_{t-1}+\gamma_{t}
\end{aligned}
$$

$E A \_C A R_{t}$ is firm $i$ 's 3-day abnormal cumulative return centered on the earnings announcement date for quarter $t$. Implied_Violation is an indicator variable that $=1$ for the most extreme quintile by year of implied covenant slack, constructed on the earnings announcement date for quarter $t$ and $=0$ otherwise. $P P_{-} I D C V_{t}$ is an indicator variable that $=1$ if Implied_Violation $=1$ in any of the previous four quarters and $=0$ otherwise. $R O A_{t}$ is net income for firm $i$ in quarter $t$ divided by assets in quarter $t-1 . R O A_{t-1}$ is the return on assets for quarter $t-1$. Loss $t$ is in indicator variable $=1$ if the firm experienced a loss in quarter $t$. Int_Coveraget I $_{-1}$ is the interest coverage ratio for firm $i$ in quarter $t-1$ and is truncated at the $1^{\text {st }}$ and $99^{\text {th }}$ percentiles. $\bar{S} U E$ is earnings for quarter $t$ less earnings for quarter $t-1$ scaled by the market value of equity in quarter $t-1$ for firm $i$ and is truncated at the $1^{\text {st }}$ and $99^{\text {th }}$ percentiles.

$L n_{-} M V E_{t-1}$ is the natural log of the market value of equity for quarter t-1. MTB is the natural log of the market value of equity divided by the book value of equity in quarter $t-1$. Curr Ratio $_{\mathrm{t}-1}$ is current assets divided by current liabilities for quarter $t-1$. Cov_Ratio is the maximum allowable value of debt-to-EBITDA for firm $i$ in quarter $t$ before a technical violation occurs. $E A \_A V A R$ is the 3-day abnormal variance centered around the earnings announcement date for firm $i$ in quarter $t$. EA_AVOL is the 3-day abnormal trading volume centered around the earnings announcement date for firm i in quarter $t$. Controls are included for covenant violation disclosures in the financial statements in the previous four quarters. The standard errors are robust to heteroskedasticity and clustered by firm. Year fixed effects are included. 
Table 7: Market Response to Covenant Violation Reversal

Dependent Variable: EA_CAR

\begin{tabular}{|c|c|c|c|c|c|c|c|c|}
\hline VARIABLES & $\begin{array}{c}\text { Coefficient } \\
\text { Estimate }\end{array}$ & $\operatorname{Pr}>|t|$ & $\begin{array}{c}\text { Coefficient } \\
\text { Estimate }\end{array}$ & $\operatorname{Pr}>|t|$ & $\begin{array}{c}\text { Coefficient } \\
\text { Estimate }\end{array}$ & $\operatorname{Pr}>|t|$ & $\begin{array}{c}\text { Coefficient } \\
\text { Estimate }\end{array}$ & $\operatorname{Pr}>|t|$ \\
\hline Intercept & 0.0047 & 0.0274 & 0.0107 & 0.0641 & 0.0116 & 0.0810 & 0.0110 & 0.0861 \\
\hline $\operatorname{Loss}_{t-1}$ & & & -0.0112 & 0.0006 & -0.0099 & 0.0039 & -0.0098 & 0.0054 \\
\hline$R O A_{t}$ & & & 0.0157 & 0.8219 & 0.0491 & 0.4911 & 0.0576 & 0.4283 \\
\hline$S U E$ & & & 0.1412 & $<.0001$ & 0.1395 & 0.0001 & 0.1392 & 0.0002 \\
\hline$M T B$ & & & -0.0052 & 0.0006 & -0.0049 & 0.0006 & -0.0048 & 0.0010 \\
\hline Ln_Assets ${ }_{t-1}$ & & & -0.0003 & 0.7104 & -0.0003 & 0.6692 & -0.0001 & 0.9138 \\
\hline Int_Coverage ${ }_{t-1}$ & & & & & -0.0001 & 0.0034 & -0.0001 & 0.0094 \\
\hline Curr_Ratio $_{t-1}$ & & & & & 0.0004 & 0.6970 & 0.0005 & 0.6338 \\
\hline Fixed Effects & \multicolumn{2}{|c|}{ Year } & \multicolumn{2}{|c|}{ Year } & \multicolumn{2}{|c|}{ Year } & \multicolumn{2}{|c|}{ Year } \\
\hline Clustered SE & \multicolumn{2}{|c|}{ Firm } & \multicolumn{2}{|c|}{ Firm } & \multicolumn{2}{|c|}{ Firm } & \multicolumn{2}{|c|}{ Firm } \\
\hline Number of Observations & \multicolumn{2}{|c|}{11,440} & \multicolumn{2}{|c|}{10,912} & \multicolumn{2}{|c|}{9,528} & \multicolumn{2}{|c|}{9,528} \\
\hline R-squared & \multicolumn{2}{|c|}{0.0018} & \multicolumn{2}{|c|}{0.0133} & \multicolumn{2}{|c|}{0.0117} & \multicolumn{2}{|c|}{0.0260} \\
\hline
\end{tabular}


Table 7 presents results from the OLS estimation of the following model using firm-quarter earnings announcements over the period 1997 to 2006 :

$$
\begin{aligned}
& E A_{-} C A R_{t}=\alpha_{0}+\alpha_{1} D C V_{-} \text {Reversal } t+\alpha_{2} \text { Loss }_{t}+\alpha_{3} R O A_{t}+\alpha_{4} R O A_{t-1}+\alpha_{5} S U E_{t-1} \\
& +\alpha_{6} M T B+\alpha_{7} \text { Ln_Assets }_{t-1}+\alpha_{8} \text { Int_Coverage }_{t-1}+\alpha_{9} \text { Curr_Ratio }_{t-1}+\alpha_{10} \text { Cov_Ratio }_{t} \\
& \alpha_{11} E A \_A V A R s_{t-1}+\alpha_{12} E A \_A V O L s_{t-1}+\gamma_{t}
\end{aligned}
$$

$E A_{-} C A R_{t}$ is firm $i$ 's 3-day abnormal cumulative return centered on the earnings announcement date for quarter $t$. $D C V \_$Reversal is an indicator variable that $=1$ for firms that had an implied violation or disclosed a violation in the previous quarter but that do not have an implied violation in the current period and that will not disclose a violation in the yet to be filed financial statements and $=0$ otherwise. $R O A_{t}$ is net income for firm $i$ in quarter $t$ divided by assets in quarter $t-1 . R O A_{t-1}$ is the return on assets for quarter $t-1$. Loss $t$ is in indicator variable $=1$ if the firm experienced a loss in quarter $t$. Int_Coverage $e_{t-1}$ is the interest coverage ratio for firm $i$ in quarter $t-l$ and is truncated at the $1^{\text {st }}$ and $99^{\text {th }}$ percentiles. SUE is earnings for quarter $t$ less earnings for quarter $t-1$ scaled by the market value of equity in quarter $t-l$ for firm $i$ and is truncated at the $1^{\text {st }}$ and $99^{\text {th }}$ percentiles. $L n_{-} M V E_{t-1}$ is the natural $\log$ of the market value of equity for quarter $\mathrm{t}-1$. MTB is the natural $\log$ of the market value of equity divided by the book value of equity in quarter $t-1$. Curr_Ratio ${ }_{t-1}$ is current assets divided by current liabilities for quarter $t-1$. Cov_Ratio is the maximum allowable value of debt-to-EBITDA for firm $i$ in quarter $t$ before a technical violation occurs. $E A \_A V A R$ is the 3-day abnormal variance centered around the earnings announcement date for firm $i$ in quarter $t$. $E A \_A V O L$ is the 3-day abnormal trading volume centered around the earnings announcement date for firm $\mathrm{i}$ in quarter $t$. The standard errors are robust to heteroskedasticity and clustered by firm. Year fixed effects are included. 


\section{Table 8: Market Response to Violation Disclosure in the Financial Statements for With an Earnings-Based Covenant Firms}

Dependent Variable: SEC_CAR

VARIABLES

\begin{tabular}{|c|c|c|c|c|}
\hline \multirow[t]{2}{*}{ VARIABLES } & \multicolumn{2}{|c|}{$\begin{array}{l}\text { Model (1) Firms With Earnings- } \\
\text { based Covenant }\end{array}$} & \multicolumn{2}{|c|}{$\begin{array}{c}\text { Model (2) Firms With } \\
\text { Implied Violation } \\
\end{array}$} \\
\hline & Estimate & p-value & Estimate & p-value \\
\hline Intercept & -0.0061 & 0.2357 & -0.0216 & 0.0776 \\
\hline $\mathrm{VIOL}_{t}$ & 0.0011 & 0.8539 & 0.0029 & 0.7086 \\
\hline $\operatorname{Loss}_{t}$ & -0.0031 & 0.2279 & -0.0023 & 0.6330 \\
\hline$R O A_{t}$ & 0.0409 & 0.1973 & 0.1784 & 0.4075 \\
\hline$R O A t-1$ & 0.0422 & 0.1285 & 0.0585 & 0.4312 \\
\hline$S U E$ & 0.0052 & 0.2726 & 0.0347 & 0.0999 \\
\hline$M T B$ & -0.0037 & 0.0011 & 0.0010 & 0.6193 \\
\hline Ln_Assets $_{t}$ & 0.0010 & 0.0677 & 0.0021 & 0.0873 \\
\hline Curr_Ratio $_{t}$ & -0.0006 & 0.2810 & -0.0002 & 0.9269 \\
\hline$S E C \_A V A R$ & 0.0004 & 0.1548 & 0.0000 & 0.9618 \\
\hline$S E C \_A V O L$ & 0.0001 & 0.8942 & -0.0002 & 0.7733 \\
\hline Fixed Effects & Yes & & Yes & \\
\hline Clustered SE & Firm & & Firm & \\
\hline Number of Observations & 11,440 & & 1,946 & \\
\hline R-squared & 0.0117 & & 0.0149 & \\
\hline
\end{tabular}
based Covenant

Implied Violation

Model (1) Firms With Earnings- Model (2) Firms With 
Table 8 presents results from the OLS estimation of the following model using firm-quarter earnings announcements over the period 1997 to 2006 :

$$
\begin{aligned}
& \text { SEC_CAR } R_{t}=\alpha_{0}+\alpha_{1} \text { VIOLt }+\alpha_{2} \text { Loss }_{t}+\alpha_{3} R O A_{t}+\alpha_{4} R O A_{t-1}+\alpha_{5} S U E_{t} \\
& +\alpha_{6} M T B+\alpha_{7} \text { Ln_Assets }_{t-1}+\alpha_{8} \text { Curr_Ratio }_{t-1}+\alpha_{9} \text { Cov }_{-} \text {Ratio }_{t} \\
& +\alpha_{10} S E C \_A V A R s_{t-1}+\alpha_{1 I} S E C \_A V O L s_{t-1}+\gamma_{t}
\end{aligned}
$$

$S E C_{-} C A R_{t}$ is firm $i$ 's 3-day abnormal cumulative return centered on the financial statement filing date for quarter $t$. $V I O L$ is an indicator variable that $=1$ if a firm $i$ disclosed a debt covenant violation in its financial statements for quarter $t$ and $=0$ otherwise. $R O A_{t}$ is net income for firm $i$ in quarter $t$ divided by assets in quarter $t-1 . R O A_{t-1}$ is the return on assets for quarter $t-1$. Loss $_{t}$ is in indicator variable $=1$ if the firm experienced a loss in quarter $t$. SUE is earnings for quarter $t$ less earnings for quarter $t-1$ scaled by the market value of equity in quarter $t-1$ for firm $i$. $L n_{-} M V E_{t-1}$ is the natural $\log$ of the market value of equity for quarter t-1. MTB is the natural $\log$ of the market value of equity divided by the book value of equity in quarter $t-1$. Curr Ratio $_{\mathrm{t}-1}$ is current assets divided by current liabilities for quarter $t-1$. Cov_Ratio is the maximum allowable value of debt-to-EBITDA for firm $i$ in quarter $t$ before a technical violation occurs. SEC_AVAR is the 3-day abnormal variance centered around the financial statement filing date for firm $i$ in quarter $t$. SEC_AVOL is the 3-day abnormal trading volume centered around the financial statement filing date for firm i in quarter $t$. The standard errors are robust to heteroskedasticity and clustered by firm. Year fixed effects are included. 


\title{
Table 9: Market Response to Violation Disclosure in the Financial Statements
}

\author{
Dependent Variable: SEC_CAR $_{t}$
}

VARIABLES

\begin{tabular}{|c|c|c|c|c|}
\hline & Estimate & p-value & Estimate & p-value \\
\hline Intercept & 0.0341 & 0.5762 & 0.0342 & 0.5753 \\
\hline$V I O L_{t}$ & -0.0043 & 0.0040 & -0.0044 & 0.0039 \\
\hline $\operatorname{Loss}_{t}$ & -0.0071 & $<.0001$ & -0.0072 & $<.0001$ \\
\hline$R O A_{t}$ & 0.0257 & $<.0001$ & 0.0256 & $<.0001$ \\
\hline ROAt-1 & -0.0060 & 0.0882 & -0.0060 & 0.0876 \\
\hline$S U E$ & -0.0001 & 0.8145 & -0.0001 & 0.8013 \\
\hline MTB & -0.0016 & $<.0001$ & -0.0016 & $<.0001$ \\
\hline Ln_Assets $_{t}$ & 0.0006 & $<.0001$ & 0.0006 & $<.0001$ \\
\hline Curr_Ratio $_{t}$ & 0.0000 & 0.9344 & 0.0000 & 0.9261 \\
\hline$S E C \_A V A R$ & 0.0013 & $<.0001$ & 0.0013 & $<.0001$ \\
\hline$S E C \_A V O L$ & -0.0005 & 0.3850 & -0.0005 & 0.3882 \\
\hline Fixed Effects & \multicolumn{2}{|c|}{ Yes } & \multicolumn{2}{|c|}{ Yes } \\
\hline Clustered SE & \multicolumn{2}{|c|}{ Firm } & \multicolumn{2}{|c|}{ Firm } \\
\hline Number of Observations & \multicolumn{2}{|c|}{168,486} & \multicolumn{2}{|c|}{157,178} \\
\hline R-squared & \multicolumn{2}{|c|}{0.1078} & \multicolumn{2}{|c|}{0.1112} \\
\hline
\end{tabular}

Model (1) Full Violation Model (2) Firms Without

Sample

EB Covenant 
liabilities for quarter $t$-1.Cov_Ratio is the maximum allowable value of debt-to-EBITDA for firm $i$ in quarter $t$ before a technical violation occurs. SEC_AVAR is the 3-day abnormal variance centered around the financial statement filing date for firm $i$ in quarter $t$. SEC_AVOL is the 3-day abnormal trading volume centered around the financial statement filing date for firm $\mathrm{i}$ in quarter $t$. The standard errors are robust to heteroskedasticity and clustered by firm. Year fixed effects are included. 
Table 10: Market Response to Implied Violation and Violation Disclosure For Accounting-based Covenant Firms

\begin{tabular}{|c|c|c|c|c|}
\hline \multirow[t]{2}{*}{ VARIABLES } & \multicolumn{2}{|c|}{$\begin{array}{c}\text { Model (1) Dep Var }= \\
\text { SEC_CAR }{ }_{t}\end{array}$} & \multicolumn{2}{|c|}{$\begin{array}{c}\text { Model (2) Dep Var }= \\
\qquad A A_{-} C A R_{t}\end{array}$} \\
\hline & Estimate & $p$-value & Estimate & p-value \\
\hline Intercept & -0.0093 & 0.6709 & -0.0051 & 0.8821 \\
\hline$V I O L_{t}$ & -0.0302 & 0.0698 & -0.0143 & 0.4323 \\
\hline$R O A_{t}$ & 0.0230 & 0.2342 & 0.0365 & 0.1374 \\
\hline$R O A_{t-1}$ & 0.1446 & 0.0074 & -0.0386 & 0.4675 \\
\hline SUE & 0.0285 & 0.4322 & 0.0278 & 0.4521 \\
\hline Cov_Ratio & 0.0102 & 0.2626 & 0.0118 & 0.2546 \\
\hline Curr_Ratio $_{t}$ & -0.0005 & 0.7038 & -0.0022 & 0.0781 \\
\hline Capex $_{t}$ & 0.0000 & 0.1797 & 0.0000 & 0.7449 \\
\hline Leverage $_{t}$ & 0.0013 & 0.1677 & -0.0001 & 0.8930 \\
\hline$M T B$ & -0.0095 & 0.0625 & -0.0056 & 0.4249 \\
\hline Ln_Assets ${ }_{t}$ & -0.0021 & 0.4738 & 0.0001 & 0.9690 \\
\hline Fixed Effects & \multicolumn{2}{|c|}{ Year } & \multicolumn{2}{|c|}{ Year } \\
\hline Clustered SE & \multicolumn{2}{|c|}{ Firm } & \multicolumn{2}{|c|}{ Firm } \\
\hline Number of Observations & \multicolumn{2}{|c|}{801} & \multicolumn{2}{|c|}{801} \\
\hline R-squared & \multicolumn{2}{|c|}{0.0476} & \multicolumn{2}{|c|}{0.0230} \\
\hline
\end{tabular}


Table 10 presents results from the OLS estimation of the following model using firm-quarter earnings announcements over the period 1997 to 2006:

$$
\begin{aligned}
& \text { CAR } R_{t}=\alpha_{0}+\alpha_{1} \text { VIOLt }+\alpha_{2} \text { Loss }_{t}+\alpha_{3} \text { ROA }_{t}+\alpha_{4} \text { ROA }_{t-1}+\alpha_{5} \text { SUE }_{t-1} \\
& +\alpha_{6} \text { MTB }+\alpha_{7} \text { Ln_Assets } s_{t-1}+\alpha_{8} \text { Curr_Ratio }_{t-1}+\alpha_{9} \text { Cov }_{-} \text {Ratio }_{t} \\
& +\alpha_{10} S E C \_ \text {AVARs } \\
& t-1+\alpha_{11} \text { SEC_AVOLs } t_{t-1}+\gamma_{t}
\end{aligned}
$$

$C A R_{t}$ is firm $i$ 's 3-day abnormal cumulative return centered on the financial statement filing or earnings announcement date for quarter $t$. VIOL is an indicator variable that $=1$ if a firm $i$ disclosed a debt covenant violation in its financial statements for quarter $t$ and $=0$ otherwise. Implied_Curr_Ratio_Viol $l_{t}$ is an indicator variable that $=1$ if the current ratio computed on the SEC filing date suggests a debt covenant violion. $R O A_{t}$ is net income for firm $i$ in quarter $t$ divided by assets in quarter $t-1 . R O A_{t-1}$ is the return on assets for quarter $t-1$. Loss $_{t}$ is in indicator variable $=1$ if the firm experienced a loss in quarter $t$. SUE is earnings for quarter $t$ less earnings for quarter $t-1$ scaled by the market value of equity in quarter $t-1$ for firm $i$. Ln_Assets $s_{t-1}$ is the natural log of firm assets for quarter $\mathrm{t}-1$. Capex is the capital expenditure for firm $i$ in quarter $t$. Leverage is the debt-to-equity ratio for firm $i$ in quarter t. MTB is the natural log of the market value of equity divided by the book value of equity in quarter $t-1$. Curr_Ratio $o_{\mathrm{t}-1}$ is current assets divided by current liabilities for quarter $t-1$. Cov_Ratio is the maximum allowable current ratio for firm $i$ in quarter $t$ before a technical violation occurs. The standard errors are robust to heteroskedasticity and clustered by firm. Year fixed effects are included. 


\section{REFERENCES}

Aghion, P., P. Bolton, 1992, An Incomplete Contracts Approach to Financial Contracting, Review of Economic Studies 59, 473-494.

Alford, A., J. Jones, and M. Zmijewski, 1994, Extensions and violations of the statutory SEC Form 10-K filing requirements, Journal of Accounting and Economics 17, 229-254.

Altman, E., 1968, Financial Ratios, Discriminant Analysis and the Prediction of Corporate Bankruptcy, Journal of Finance 23, 589-609.

Baird, D., R. Rasmussen, 2006, Private Debt and the Missing Lever of Corporate Governance, University of Pennsylvania Law Review 154, 1209-1251.

Beaver, W., 1966, Financial Ratios As Predictors of Failure, Journal of Accounting Research 4, 71111.

Beaver, W., 1968, The Information Content of Annual Earnings Announcements, Journal of Accounting Research 6, 67-92.

Beatty, A., and J. Weber, 2003, The Effects of Debt Contracting on Voluntary Accounting Method Changes, The Accounting Review 78, 119-142.

Beneish, M., and E. Press, 1993, Costs of Technical Violation of Accounting-Based Debt Covenants, The Accounting Review 68, 233-257.

Beneish, M., and E. Press, 1995, The Resolution of Technical Default, The Accounting Review 70, 337-353.

Bharath, S., J. Sunder, and S. Sunder, 2008, Accounting Quality and Debt Contracting, The Accounting Review 83, 1-28.

Bradley, M., M. Roberts, 2004, The Structure and Pricing of Corporate Debt Covenants, Working paper.

Chava, S., and M. Roberts, 2008, How Does Financing Impact Investment? The Role of Debt Covenants, Journal of Finance 63, 2085-2121.

Chen, K., and K.C. Wei, 1993, Creditors' Decisions to Waive Violations of Accounting-Based Debt Covenants, The Accounting Review 68, 218-232.

Collins, D., O. Li, and H. Xie, 2009, What drives the increased informativeness of earnings announcements over time?, Review of Accounting Studies 14, 1-30.

Core, J., and C. Schrand, 1999, The effect of accounting-based debt covenants on equity valuation, Journal of Accounting and Economics 27, 1-34. 
DeFond, M., and J. Jiambalvo, 1994, Debt covenant violation and manipulation of accruals, Journal of Accounting and Economics 17, 145-176.

Denis, D., and V. Mihov, The choice among bank debt, non-bank private debt, and public debt: evidence from new corporate borrowings, Journal of Financial Economics 70, 3-28.

Dichev, I., and D. Skinner, 2002, Large-Sample Evidence on the Debt Covenant Hypothesis, Journal of Accounting Research 40, 1091-1123.

Dyreng, S., 2009, Predicting Private Debt Covenant Violation, Working paper.

Fama, E., and K. French, 1992, The Cross-Section of Expected Stock Returns, Journal of Finance 47, 427-465.

Francis, J., K. Schipper, and L. Vincent, 2002, Expanded Disclosures and the Increased Usefulness of Earnings Announcements, The Accounting Review 77, 515-546.

Gilson, S., 1990, Bankruptcy, boards, banks, and blockholders, Journal of Financial Economics 27, 355-387.

Griffin, P., D. Lont, and K. McClune, 2010, Insightful Insiders? Insider Trading and Stock Return Around Debt Covenant Violation Disclosures, Working paper.

Hayn, C., 1995, The information content of losses, Journal of Accounting and Economics 20, 125 153.

Jensen, M., and W. Meckling, 1976, Theory of the Firm: Managerial Behavior, Agency Costs and Ownership Structure, Journal of Financial Economics 3, 305-360.

Jiang, J., 2008, Beating Earnings Benchmarks and the Cost of Debt, The Accounting Review 83, $377-416$.

Landsman, W., and E. Maydew, 2002, Has the Information Content of Quarterly Earnings Announcements Declined in the Past Three Decades?, Journal of Accounting Research 40, 797808.

Leftwich, R., 1983, Accounting Information in Private Markets: Evidence from Private Lending Agreements, The Accounting Review 58. 23-42.

Murfin, J., 2009, The Supply-Side Determinants of Loan Contract Strictness, Working paper.

Nini, G., D. Smith, and A. Sufi, 2009, Creditor Control Rights, Corporate Governance, and Firm Value, Working paper.

Roberts, M., A. Sufi, 2009a, Control Rights and Capital Structure: An Empirical Investigation, Journal of Finance 64, 1657-1695. 
Roberts, M., A. Sufi, 2009b, Financial Contracting: A Survey of Empirical Research and Future Directions, The Annual Review of Financial Economics 1, 1-20.

Roberts, M., A. Sufi, 2009c, Renegotiation of financial contracts: Evidence from private credit agreements, Journal of Financial Economics 93, 159-184.

Skinner, D., 1994, Why Firms Voluntarily Disclose Bad News, Journal of Accounting Research 32, 38-60.

Skinner, D., and R. Sloan, 2002, Earnings Surprises, Growth Expectations, and Stock Returns or Don't Let an Earnings Torpedo Sink Your Portfolio, Review of Accounting Studie 7, 289-312.

Smith, C., 1993, A Perspective on Accounting-Based Debt Covenant Violations, The Accounting Review 68, 289-303.

Sufi, A., 2007, Information Asymmetry and Financing Arrangements: Evidence from Syndicated Loans, Journal of Finance 62, 629-668.

Sufi, A., 2009, Bank Lines of Credit in Corporate Finance: An Empirical Analysis, Review of Financial Studies 22, 1057-1088.

Sweeney, A., 1994, Debt-covenant violations and managers' accounting responses, Journal of Accounting and Economics 17, 281-308.

Watts, R., and J. Zimmerman, 1978, Towards a Positive Theory of the Determination of Accounting Standards, The Accounting Review 53, 112-134. 